Review

\title{
MicroRNAs linking inflamm-aging, cellular senescence and cancer
}

\author{
Q1 Fabiola Olivieria ${ }^{\mathrm{a}, \mathrm{b}}$, Maria Rita Rippo ${ }^{\mathrm{a}}$, Vladia Monsurro ${ }^{\mathrm{c}}$, Stefano Salvioli ${ }^{\mathrm{d}, \mathrm{e}}$, \\ Miriam Capri ${ }^{\mathrm{d}, \mathrm{e}}$, Antonio Domenico Procopio ${ }^{\mathrm{a}, \mathrm{b}}$, Claudio Franceschi ${ }^{\mathrm{d}, \mathrm{e}, *}$ \\ a Department of Clinical and Molecular Sciences, Università Politecnica delle Marche, Ancona, Italy \\ ${ }^{\mathrm{b}}$ Center of Clinical Pathology and Innovative Therapy, I.N.R.C.A. National Institute, Ancona, Italy \\ ${ }^{\mathrm{c}}$ Department of Pathology and Diagnostic, University of Verona Medical School, Verona, Italy \\ ${ }^{\mathrm{d}}$ Department of Experimental, Diagnostic and Specialty Medicine, Alma Mater Studiorum University of Bologna, Bologna, Italy \\ e Interdepartmental Center L. Galvani “CIG”, Alma Mater Studiorum University of Bologna, Bologna, Italy
}

\section{A R T I C L E I N F O}

\section{Article history:}

Received 31 January 2013

Received in revised form 30 April 2013

Accepted 8 May 2013

Available online $\mathrm{xxx}$

\section{Keywords:}

MicroRNA

Cancer

Inflamm-aging

Centenarians

Cellular senescence

NF- $\mathrm{B}$

\begin{abstract}
A B S T R A C T
Epidemiological and experimental data demonstrate a strong correlation between age-related chronic inflammation (inflamm-aging) and cancer development. However, a comprehensive approach is needed to clarify the underlying molecular mechanisms. Chronic inflammation has mainly been attributed to continuous immune cell activation, but the cellular senescence process, which may involve acquisition of a senescence-associated secretory phenotype (SASP), can be another important contributor, especially in the elderly. MicroRNAs (miRs), a class of molecules involved in gene expression regulation, are emerging as modulators of some pathways, including NF- $\mathrm{B}, \mathrm{mTOR}$, sirtuins, TGF- $\beta$ and Wnt, that may be related to inflammation, cellular senescence and age-related diseases, cancer included. Interestingly, cancer development is largely avoided or delayed in centenarians, where changes in some miRs are found in plasma and leukocytes. We identified miRs that can be considered as senescence-associated (SA-miRs), inflammation-associated (inflamma-miRs) and cancer-associated (onco-miRs). Here we review recent findings concerning three of them, miR-21, -126 and -146a, which target mRNAs belonging to the NF-кB pathway; we discuss their ability to link cellular senescence, inflamm-aging and cancer and their changes in centenarians, and provide an update on the possibility of using miRs to block accumulation of senescent cells to prevent formation of a microenvironment favoring cancer development and progression.
\end{abstract}

\section{Contents}

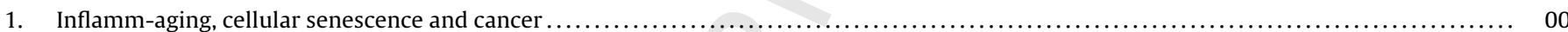

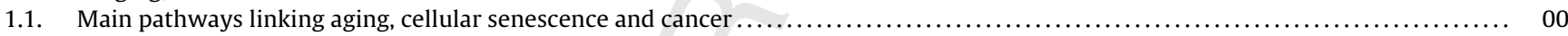

1.2. MiRs targeting the NF-кB pathway: new potential biomarkers of inflamm-aging, cellular senescence and cancer .................. 00

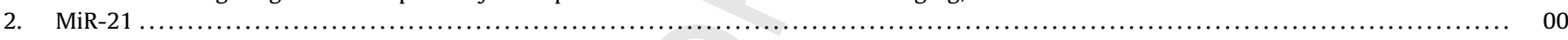

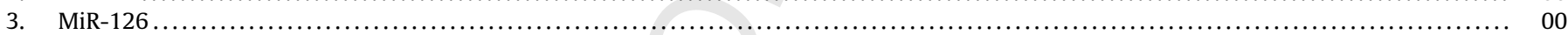

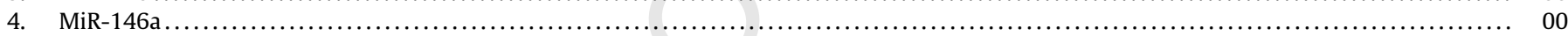

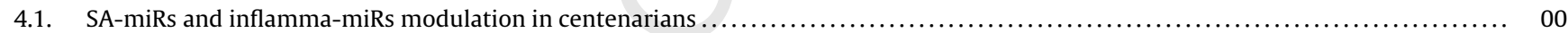

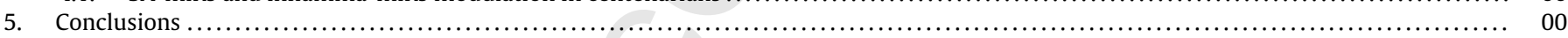

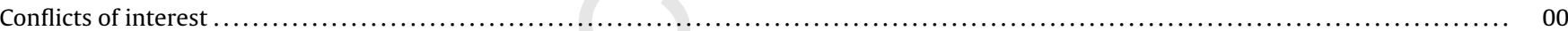

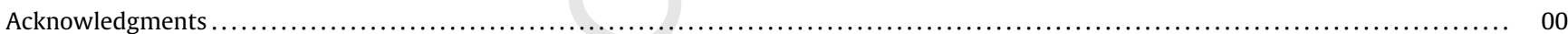

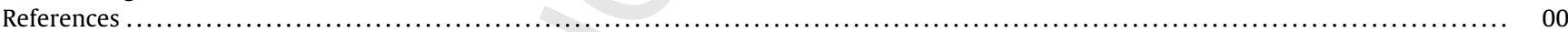

* Corresponding author at: Claudio Franceschi, Department of Experimental, Diagnostic and Specialty Medicine, CIG - Centro Interdipartimentale "L. Galvani", Via S. Giacomo, 12 Alma Mater Studiorum University of Bologna, Bologna, Italy. Tel.: +39051209 4743; fax: +390512094747.

E-mail address: claudio.franceschi@unibo.it (C. Franceschi).

\section{Inflamm-aging, cellular senescence and cancer}

Human aging is attended by a low-grade systemic inflammation characterized by elevation of circulating acute-phase proteins and proinflammatory cytokines, a condition that we have designated inflamm-aging (Franceschi et al., 2000, 2007). Such inflammatory 
43 imbalance is associated with frailty and the development and progression of severe, age-related conditions that include cardiovascular disease (CVD), type 2 diabetes mellitus (T2DM), and neurodegenerative diseases (Franceschi et al., 2007; Vasto et al., 2007; Cevenini et al., 2013). The chronic inflammation seems largely attributable to progressive activation of immune cells over time (Franceschi et al., 2007). However, recent studies show that the cellular senescence process could be an important additional contributor to the maintenance of low-grade chronic systemic inflammation (Campisi, 2011; Freund et al., 2010; Olivieri et al., 2012a,b). Besides limitations in cell replication properties, senescence may involve acquisition of the senescence-associated secretory phenotype (SASP), a distinctive phenotype characterized by enhanced secretion of the main proinflammatory mediators, i.e. proteases, cytokines, chemokines and growth factors (Campisi, 2011). Interestingly, the SASP has been documented not only in immune cells like macrophages (Sikora et al., 2011), but also in fibroblasts (Freund et al., 2010) and endothelial cells (Olivieri et al., 2012a,b; Donato et al., 2008). SASP acquisition helps explain some Q2 of the biological activities of senescent cells, notably their contribution to tissue repair; indeed increased production of cytokines and chemokines is capable of inducing recruitment of phagocytes, which can eliminate dysfunctional cells thus favoring the reparative capacity of tissues (Rodier and Campisi, 2011). Moreover cellular senescence, by limiting cell proliferation, can prevent the growth of cells with damaged DNA, which are at risk of neoplastic transformation (Rodier and Campisi, 2011). Although senescent cells contribute to repair processes and are protected from malignant transformation, their age-related accumulation can at the same time promote a systemic chronic proinflammatory status that favors the development of the major age-related diseases sharing an inflammatory background and creates a pro-tumorigenic environment, contributing to carcinogenesis and metastasis formation (Rodier and Campisi, 2011; Schetter et al., 2010; Bonafè et al., 2012). In fact the inflammatory cytokines, chemokines, growth factors and extracellular matrix-degrading proteases secreted by senescent cells are capable of enhancing proliferation, invasiveness and angiogenesis of nearby premalignant tumor cells (Rodier and Campisi, 2011). Specifically, the SASP turns senescent fibroblasts into proinflammatory cells with the ability to promote tumor progression, partly by inducing epithelial-mesenchymal transition (EMT) in nearby epithelial cells (Laberge et al., 2012). Further, senescent fibroblasts and mesothelial cells secrete vascular endothelial growth factors (VEGF) (Coppè et al., 2006; Li et al., 2012a,b) that stimulate endothelial cell migration and invasion, two critical steps in tumor-initiated angiogenesis (Coppè et al., 2010; Kapoor and Deshmukh, 2012). Senescent fibroblasts and keratinocytes also secrete matrix metalloproteinases, which facilitate tumor cell invasion. Moreover the SASP is not a mere consequence of the senescence status, since its maintenance requires sustained and continuous signaling (Angelini et al., 2013). Cellular senescence, which is a well-established anticancer mechanism in young and adult individuals, can thus paradoxically promote cancer at an advanced age through its secretory phenotype. Clearly cancer is primarily an age-related disease, and accumulation of senescent cells during aging has been reported in a variety of mitotically competent mammalian tissues prone to cancer development and progression (Erusalimsky and Kurz, 2005; Jeyapalan et al., 2007; Wang et al., 2009). Moreover, the observation that the SASP is a feature not only of replicative senescence but also of oncogene-induced senescence (OIS) reinforces the hypothesis linking senescence-associated inflammation to cancer development (Ren et al., 2009). In particular, up-regulation of several inflammatory modulators has been described in different cell types undergoing OIS (Kuilman et al., 2008). In addition, introduction of oncogenic RAS into arterial smooth muscle cells induced
OIS and enhanced expression of proinflammatory cytokines and chemokines (Minamino et al., 2003). Taken together these findings demonstrate that both replicative senescence and OIS activate an inflammatory response in cells of different origins.

Interestingly, the genetic patterns of cellular senescence show a high degree of similarity to those of the major age-related diseases, including CVD, T2DM and cancer (Jeck et al., 2012; Tacutu et al., 2011). Global transcriptome analysis of senescent cells disclosed a unique gene expression pattern that differs from those seen in proliferating cells and in cells undergoing quiescence or growth arrest induced by contact inhibition. Besides cell cycle regulatory genes other genes, including inflammation and stress-associated genes, DNA damage checkpoint genes, genes encoding extracellular matrix-degrading enzymes, cytoskeletal genes, and metabolic genes usually exhibit an altered expression during replicative and premature senescence and during development of age-related diseases (Jeck et al., 2012; Hardy et al., 2005).

According to a recent unified model, altered autophagy ("selfeating") could interconnect aging, inflammation and cancer (Lisanti et al., 2011). Autophagy is involved in major cancer networks, including those driven by p53, mammalian target of rapamycin (mTOR) complex, RAS and glutamine pathways, and also protects organisms against the development of other diseases, including inflammatory and neurodegenerative conditions (Liu et al., 2012). The aging process is associated with a decline in autophagic capacity that can lead to aberrant protein aggregation and accumulation of dysfunctional mitochondria (He et al., 2013a,b). These phenomena induce production of reactive oxygen species (ROS), which in turn can trigger inflammation via activation of inflammasomes, facilitating the development and progression of a number of human diseases including cancer (Salminen et al., 2012). In hepatocellular carcinoma, the most common primary malignant liver tumor, loss of toll-like receptor 2 (TLR-2)-mediated immune activity and the senescence status impair the autophagic process, leading to increased ROS production and DNA damage (Lin et al., 2012a,b).

Thus, even though cellular senescence is emerging as an effective transcriptional program that can be adaptively activated to promote the regenerative ability of damaged or aged tissues, it can paradoxically promote the development of the major agerelated diseases at the same time. SASP identification therefore seems to have clinical relevance. Several markers have been identified that can, at least partially, discriminate senescence from other forms of growth arrest such as quiescence: (i) increased expression of senescence-associated $\beta$-galactosidase (SA- $\beta$-gal), a pH-dependent lysosomal $\beta$-gal encoded by the GLB1 gene, which partly reflects the increased lysosomal mass found in senescent cells (Lee et al., 2006); (ii) increased expression of p16 ${ }^{\mathrm{INK} 4 \mathrm{~A}}$ and $\mathrm{p} 15^{\mathrm{INK} 4 \mathrm{~B}}$, two small proteins involved in cell cycle arrest as inhibitors of cyclin-dependent kinases (CDKs) (Ren et al., 2009); (iii) increased expression of distinct chromatin structures known as senescence-associated heterochromatic foci, which may be responsible for the selective gene expression silencing required for the stability of the senescence transcriptional program (Ren et al., 2009); and (iv) telomere attrition and reduced telomerase activity, which impair replicative ability.

Notably, although most of these markers have been identified in senescent cells in vitro, a relationship between senescence of cultured cells and the organismal life span has never been proved conclusively (Campisi, 2001; Zhao et al., 2009). A recent study using stationary cells as an in vitro model of aging found more intracellular changes similar to those of an aging organism in stationary cell cultures than in cells undergoing replicative senescence (Khokhlov, 2013).

Several reports have documented the accumulation of senescent cells in vivo and their effects on the micro- and macroenvironment (Campisi and Sedivy, 2009). Progressive age-related accumulation 
Table 1

Main pathways linking inflammation, cellular senescence and cancer.

\begin{tabular}{ll}
\hline Pathways & Physiological effects \\
\hline NF- $\kappa$ B signaling & Stress response \\
mTOR complex & Optimization of energy harvesting, autophagy \\
Sirtuins & Optimization of energy harvesting \\
TGF- $\beta$ & Stress response \\
Wnt & Cell proliferation
\end{tabular}

mTOR, mammalian target of rapamycin; NF- $\mathrm{B}$, nuclear factor $\kappa \mathrm{B}$; TGF- $\beta$, transforming growth factor $\beta$; Wnt, glycoproteins acting as ligands to produce cell responses playing a variety of important roles.

of senescent mesenchymal stem cells (MSCs) was reported in bone marrow of rhesus monkeys (Yu et al., 2011). Intrinsic age-related changes were also observed in human MSCs, contributing to the process of skeletal aging (Zhou et al., 2008). Increased numbers of senescent cells were noted in human tissues not only during normal aging, but also in damaged or wounded tissue (Campisi, 2011; Collado et al., 2005; Michaloglou et al., 2005). Senescent cells were also demonstrated in pathological states, such as degenerative aging diseases (Burton, 2009). Senescent cell accumulation was reported in hyperplastic, preneoplastic, and early neoplastic lesions, suggesting that they could stimulate proliferation of premalignant and malignant cells, thus contributing to carcinogenesis (Burton, 2009).

However, the extension of these findings to clinical research is currently hampered by the lack of specific cell senescence markers and of non-invasive techniques capable of assessing cellular senescence in vivo (Erusalimsky and Kurz, 2005).

Identification and validation of new molecules involved in SASP modulation would enhance our understanding of the molecular mechanism involved in physiological and pathological aging and provide new diagnostic tools and treatment options for patients with the major age-related diseases, including cancer. In this context, miRs are highly promising biomarkers of inflamm-aging, cellular senescence and cancer. Their emerging role as regulators of inflamm-aging, cellular senescence and cancer pathways is discussed herein and the hypothesis that some miRs modulate the processes involved in longevity is advanced and examined in relation to evidence obtained in centenarians.

\subsection{Main pathways linking aging, cellular senescence and cancer}

Over the past few years, several lines of evidence have disclosed that a number of pathways may be molecular interfaces connecting aging, senescence and cancer (Table 1).

Nuclear factor (NF)- $\kappa \mathrm{B}$ signaling is among the pathways most closely involved in stimulating SASP acquisition and cancer development, and may therefore have an important role in inflammation as well as tumorigenesis (Ben-Neriah and Karin, 2011; Li et al., 2011; Karin, 2006; Salminen et al., 2012a; Olivieri et al., 2011; Quinn and O'Neill, 2011; Gorospe and Abdelmohsen, 2011). NF$\kappa \mathrm{B}$ is a family of structurally related transcription factors, that in mammals include RelA (p65), RelB, c-Rel, p50/p105, and p52/p100, which bind to DNA and regulate target gene transcription as homoand heterodimers.

Interestingly, non-NF- $\mathrm{B}$-mediated pathways may also link inflammation, senescence and cancer. mTOR is a highly conserved serine/threonine kinase that controls cell growth and metabolism in response to nutrients, growth factors, cell energy imbalance and stress (Blagosklonny, 2011). mTOR complex 1 and 2 (mTORC1 and 2) regulate other important kinases, such as S6 kinase (S6K) and AKT (Zoncu et al., 2011). Over-activation of such sensory signal transduction pathways can cause cellular senescence and agerelated diseases, including cancer, and shorten life span (Hall, 2008; Berman et al., 2012).
Sirtuins, a class of $\mathrm{NAD}(+)$-dependent deacetylases, also play important roles in aging and common age-associated diseases (Morris, 2013). Whereas SIRT1 is well explored (Morris, 2013), a role is now emerging for other sirtuins as enhancers of fat metabolism and modulators of mitochondrial respiration to optimize energy production. Down-regulation of sirtuins can largely account for the patho-physiological changes taking place during aging, including cancer development. Indeed recent data indicate that down-regulation of SIRT genes may contribute to cancer development and trigger an increase in its malignancy (Lai et al., 2013).

The transforming growth factor (TGF)- $\beta$ signaling pathway can interconnect inflammation, senescence and cancer. TGF- $\beta$ has a dual role in tumor progression, initially as a suppressor and subsequently as a promoter. Autocrine TGF- $\beta$ signaling is an integral part of the cellular anti-transformation network, inducing senescence in tumor cells and/or suppressing the expression of several genes, including p21-regulated genes, that mediate oncogene-induced transformation (Lin et al., 2012a,b; Wu et al., 2009; Senturk et al., 2010). However, even though TGF- $\beta$ can hinder tumorigenesis by preventing cell proliferation or inducing apoptosis, during tumorigenesis cells can acquire invasive and metastatic phenotypes in response to it (Parvani et al., 2011). Recent findings indicate that the initiation of the oncogenic activity of TGF- $\beta$ is dependent on imbalances between its canonical and non-canonical signaling systems (Parvani et al., 2011).

Canonical Wnt signaling, governed by its effector $\beta$-catenin, has long been known to play an important role in cell development, tissue homeostasis, and cancer (Kim et al., 2013). Wnt expression declines during aging, and activation of multiple pathways suppressing $\beta$-catenin-dependent signaling contributes to the initiation of senescence (Varecza et al., 2011). Moreover, it has recently been shown that expression of TRF2 protein, the DNA-binding protein essential for telomere protection and chromosome stability, is activated by the Wnt/ $\beta$-catenin signaling pathway both in human cancer and normal cells (Diala et al., 2013). Overall, the Wnt/ $\beta$-catenin pathway seems to play a critical role in aging (Zhang et al., 2011; Tsaousi et al., 2011). Interestingly, endothelial inflammation is regulated by $\beta$-cateninindependent Wnt signaling, suggesting an involvement of this pathway also in modulating inflammation (Kim et al., 2010). Recent studies describe deregulated Wnt signaling in degenerative and inflammatory CNS disorders, suggesting an involvement of Wnts in inflammation-driven brain damage and inflammation-directed brain repair (Marchetti and Pluchino, 2013).

\subsection{MiRs targeting the NF- $\kappa B$ pathway: new potential} biomarkers of inflamm-aging, cellular senescence and cancer

MiRs are a broad class of small, non-coding RNAs that have revolutionized our understanding of gene transcription and translation. More than 1000 human miRs have been identified, making them one of the most abundant classes of regulatory molecules (Park and Kim, 2013; Neilsen et al., 2012). MiRs were thought to act mainly as negative regulators of gene expression by binding to 3'-UTR regions of their target protein-coding mRNAs in a sequencedependent manner (Nilsen, 2007; Baek et al., 2008). However, recent data show that $\mathrm{miR}$ regulation entails a far more complex post-transcriptional control, both repressing and activating gene expression, by interacting with complementary sequences in coding and non-coding regions of their mRNA targets (Breving and Esquela-Kerscher, 2010). Since the specificity of miR targeting is mediated only by 6-11 nucleotides, a single miR can target hundreds of mRNAs (Park and Kim, 2013). However, groups of miRs can induce regulation of specific biological processes by acting in a co-ordinated manner on pathways of functionally related genes (Cloonan et al., 2011). Thus, miRNAs have been proposed as the 
291 main players in the evolution of organismal complexity (Berezikov, 2011). Not surprisingly, miRs have recently been indicated also as regulators of organismal aging (Inukai and Slack, 2013).

MiRs have been reported to act through autocrine and/or paracrine mechanisms (Raitoharju et al., 2011; Kumarswamy et al., 2011). In addition, circulating miRs can act as hormones, eliciting a systemic response (Wahlgren et al., 2012). Recent studies show that transfer of nucleic acids, including miRs, can be an important means of intercellular communication. Transfer of information can occur by direct cell-cell contact, for instance via gap junctions, or by cell-contact-independent mechanisms, including release of microvesicles into surrounding tissue (Collino et al., 2010; Hosoda et al., 2011) or the blood stream; for example, plasma exosomes can deliver exogenous short interfering RNA to monocytes and lymphocytes (Wahlgren et al., 2012).

Discovery of the important role of miRs as gene expression regulators has shed light on a number of biological processes. Notably, several miRs contribute to the complex molecular mechanisms involved in cell growth, differentiation and survival, all processes related to cancer development and progression (Tacutu et al., 2011; Lovat et al., 2011; Keller et al., 2012). However they also play an important role in modulating inflammation and cellular senescence (Bhaumik et al., 2009; Tacutu et al., 2010), and miRs specifically involved in the inflammatory response have been shown to be modulated in both senescent and cancer cells (Paik et al., 2011; Schetter et al., 2010, 2009).

Most of the miRs targeting the NF- $\kappa$ B pathway and its modulators affect NF- $\kappa$ B signaling dynamics primarily through a negative feedback loop aimed at restraining the excessive proinflammatory response induced by signaling activation (Olivieri et al., 2012a,b; Zhao et al., 2011; Boldin and Baltimore, 2012; Vaz et al., 2011). An altered expression of the miRs targeting this pathway may thus contribute to the dysregulation of the inflammatory/antiinflammatory balance, promoting carcinogenesis (Kundu and Surh, 2012). Moreover, it has recently been observed that miRs can act as agonists of single-stranded RNA-binding TLRs, inducing NF$\kappa \mathrm{B}$ signaling activation and interleukin secretion, thus triggering a proinflammatory response that can promote the creation of a microenvironment favorable to cancer development and growth (Fabbri et al., 2012, 2013). Therefore it is possible that senescent cells contribute to inflammation not only by producing proinflammatory and proangiogenic molecules typical of SASP, but also by transferring miRs into other proinflammatory cells, namely macrophages. This evidence raises a number of questions on the potential involvement of miRs in modulating two opposite phenomena, the irreversible growth arrest observed in replicative/OIS and carcinogenesis (Martinez et al., 2011a,b; Wang et al., 2012). It is therefore essential to identify the gene targets of these miRs and clarify how their products promote or inhibit senescence and/or cancer development.

Several miRs exert pleiotropic effects in controlling a number of important biological functions via well-connected networks, thus modulating shared target pathways. It is conceivable that secretion of SASP-associated miRs could be a component of the SASP signature, and that these miRs are deregulated both in cancer and in damaged and aged tissues (Wang et al., 2011; Rodier and Campisi, 2011). Here we discuss some miRs exerting pleiotropic effects on pathways related to inflammation, senescence, and carcinogenesis. Quite a large number of miRs have been reported to play a role in modulating cellular senescence and inflammatory responses (SA-miRs and inflamma-miRs, respectively). The most extensively studied SA-miRs and inflamma-miRs are listed in Tables 2 and 3. Given the interest elicited by this new area of research, more and more miRs are expected to be identified in the near future; some of them are likely to be regulators of inflammation and senescence. We selected a subset of miRs belonging to SA-miRs and
inflamma-miRs that includes miR-9, -19b, -20a, -21, -29, -126, 145a, -155, -181a and let-7 (in bold in Tables 2 and 3). Interestingly, all these miRs, which we have identified on the basis of our experimental work and of literature data as being both SA-miRs and inflamma-miRs, are modulated in human cancers (Table 4).

Here we review and discuss in detail the role of miR-21 and $-146 \mathrm{a}$ on NF- $\mathrm{BB}$ pathway modulation in aging and age-related diseases, because there is considerable evidence that they act as SA-miRs and inflamma-miRs and play a role in modulating NF- $\mathrm{B}$ signaling (Anad and Cheresh, 2011; Zhou et al., 2011; Kumarswamy et al., 2011; Olivieri et al., 2013). MiR-126 is also included because it is involved in vascular function and inflammation by targeting adhesion molecules and members of NF- $\mathrm{B}$ signaling, two phenomena that are related to cancer development and progression (Tetè et al., 2012; Oglesby et al., 2012). The complex scenario of the pleiotropic and cross-linked functions of miR-21,-126 and -146a in relation to the main processes and diseases associated with inflammation and cancer is illustrated using Ingenuity Pathway Analysis (Fig. 1).

\section{MiR-21}

MiR-21 is a well-known cancer-associated miR (onco-miR) that is overexpressed in most human tumors; it promotes malignant growth and progression by acting on multiple targets (Kumarswamy et al., 2011). Global miR expression analysis has disclosed that it is overexpressed in highly aggressive tumors. MiR-21 targets phosphatase and tensin homolog PTEN, an upstream negative regulator of mTOR. By targeting PTEN miR-21 leads to mTOR activation and consequently to tumor progression (Cingarlini et al., 2012); it also induces tumor angiogenesis and through it activation of the AKT and ERK1/2 signaling pathways, thereby enhancing hypoxia-inducible factor 1 , alpha subunit (HIF-1 $\alpha$ ) and VEGF expression (Liu et al., 2011). Interestingly, miR-21 overexpression and NF- $\kappa \mathrm{B}$ activation have been described in cancer, even though further evidence is needed to dissect the role of miR-21 in NF- $\kappa B$ signaling and inflammation (Ma et al., 2011).

Recent data support a critical role for DNA damage-induced NF$\mathrm{KB}$ activation in promoting metastasis in breast cancer following genotoxic treatment, and miR-21 seems to contribute to this induction (Niu et al., 2012). Cell-type specificity may cause differences of miR-21 expression in NF- $\kappa$ B activity: in epithelial cells, miR-21 acts to down-regulate PTEN, activate AKT, and increase NF- $\kappa$ B activation; in LPS-stimulated macrophages, miR-21 negatively regulates programmed cell death 4 (PDCD4), which activates NF-кB through a still unknown mechanism (Ma et al., 2011).

An additional pro-tumorigenic effect of miR-21 is the formation of ROS, which mediate tumorigenesis and modulate EMT and the presence of cancer stem cells in the tumor, factors that contribute to tumor invasion and metastasis formation (Han et al., 2012).

Intriguingly, MiR-21 is also involved in promoting inflammation. Its overexpression enhances the inflammatory response by augmenting the expression of adhesion molecules in vascular cells, hence monocyte adhesion. Furthermore miR-21 is able to reduce the expression of potent human anti-inflammatory molecules such as interleukin (IL)-10 and TGF- $\beta$ (Merline et al., 2011). In line with these findings we have recently identified increased circulating levels of miR-21 as a biomarker of inflammaging (Olivieri et al., 2012a,b). MiR-21 constitutes a direct link between the tumor-associated-inflammatory status and cancer development/progression: on the one hand, increased miR-21 levels in cancer and other age-related diseases could impair the anti-inflammatory response by making the cytokine profile more proinflammatory, on the other miR-21 could promote endothelial activation, enhancing the proinflammatory response. These data 
Table 2

Main senescence-associated miRNAs (SA-miRs).

\begin{tabular}{|c|c|c|c|}
\hline MicroRNAs & Cell types & mRNA Targets & References \\
\hline MiR-9 & Mouse embryonic fibroblasts & SIRT1 & Saunders et al. (2010) \\
\hline MiR-10A* & Bone marrow-derived EPCs from mouse & \multirow[t]{4}{*}{ Hmga2 } & Zhu et al. (2013) \\
\hline MiR-17 & Replicative cell aging models & & Hackl et al. (2010) \\
\hline MiR-19b & Replicative cell aging models & & Hackl et al. (2010) \\
\hline $\operatorname{MiR}-20^{\circ}$ & Replicative cell aging models & & Hackl et al. (2010) \\
\hline MiR-21 & $\begin{array}{l}\text { Human endothelial cells, bone } \\
\text { marrow-derived EPCs from mouse }\end{array}$ & NFIB, CDC25A, Hmga2 & $\begin{array}{l}\text { Dellago et al. (2013), Zhu et al. } \\
\text { (2013) }\end{array}$ \\
\hline MiR-22 & Human fibroblasts & CDK6, SIRT1, Sp1 & Xu et al. (2011) \\
\hline MiR-29 & HeLa cell lines & B-Myb & Martinez et al. (2011a,b) \\
\hline MiR-30 & HeLa cell lines & B-Myb & Martinez et al. (2011a,b) \\
\hline $\operatorname{MiR}-34^{\circ}$ & $\begin{array}{l}\text { Rat bone marrow-derived EPCs, HUVECs, } \\
\text { Primary human TIG3 fibroblasts, Mesangial } \\
\text { cells }\end{array}$ & $\begin{array}{l}\text { SIRT1, } \\
\text { MYC, } \\
\text { Txnrd2 }\end{array}$ & $\begin{array}{l}\text { Zhao et al. (2010), Ito et al. (2010), } \\
\text { Christoffersen et al. (2010), Bai } \\
\text { et al. (2011) }\end{array}$ \\
\hline MiR-101 & Human diploid fibroblasts & Ezh2 & Greussing et al. (2013) \\
\hline MiR-106 & $\begin{array}{l}\text { Human mammary epithelial cells, Replicative } \\
\text { cell aging models }\end{array}$ & p21 & $\begin{array}{l}\text { Borgdorff et al. (2010), Hackl et al. } \\
\text { (2010) }\end{array}$ \\
\hline MiR-126 & HAECs & VCAM-1 & Rippe et al. (2012) \\
\hline MiR-138 & ATC & hTERT & Mitomo et al. (2008) \\
\hline $\begin{array}{l}\text { MiR-146a, } \\
\text { miR-146b }\end{array}$ & $\begin{array}{l}\text { Bone marrow derived DCs, Dermal fibroblasts, } \\
\text { HUVECs, Trabecular meshwork cells, } \\
\text { Fibroblasts, Primary human TIG3 fibroblasts }\end{array}$ & IRAK-1, TRAF-6 & $\begin{array}{l}\text { Park et al. (2012), Olivieri et al. } \\
\text { (2011), Li et al. (2010a,b), Bhaumik } \\
\text { et al. (2009), Christoffersen et al. } \\
\text { (2010) }\end{array}$ \\
\hline MiR-152 & Dermal fibroblasts & $\begin{array}{l}\text { integrin } \alpha 5 \text {, collagen } \\
\mathrm{XVI}\end{array}$ & Mancini et al. (2012) \\
\hline MiR-155 & $\begin{array}{l}\text { Bone marrow-derived DCs, } \\
\text { HDFs }\end{array}$ & $\begin{array}{l}\text { DC-SIGN } \\
\text { c-Jun }\end{array}$ & Park et al. (2012), Song et al. (2012) \\
\hline MiR-181 & Dermal fibroblasts, CD4(+) T cells & $\begin{array}{l}\text { integrin } \alpha 5 \text {, collagen } \\
\mathrm{XVI}\end{array}$ & $\begin{array}{l}\text { Mancini et al. (2012), Li et al. } \\
(2012 a, b)\end{array}$ \\
\hline MiR-191 & Keratinocytes & SATB1, CDK6 & Lena et al. (2012) \\
\hline MiR-217 & HUVECs, HAECs, HCAECs & SIRT1 & Menghini et al. (2009) \\
\hline MiR-221 & HAECs & eNOS & Rippe et al. (2012) \\
\hline MiR-222 & HAECs & eNOS & Rippe et al. (2012) \\
\hline MiR-299-3p & Endothelial cells & IGF1 & Jong et al. (2013) \\
\hline MiR-335 & Mesangial cells & SOD2 & Bai et al. (2011) \\
\hline MiR-519 & WI-38 human diploid fibroblasts & HuR & Marasa et al. (2010) \\
\hline Let-7 & MEFs & $\mathrm{EZH} 2$ & Toledano (2012), Tzatsos et al. \\
\hline & Premalignant cancer cells & $\mathrm{RB} 1 / \mathrm{E} 2 \mathrm{~F}$ & (2011), Benhamed et al. (2012) \\
\hline
\end{tabular}

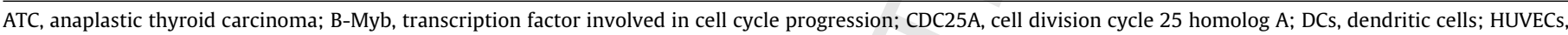

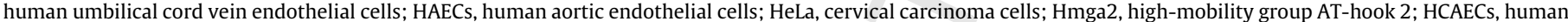

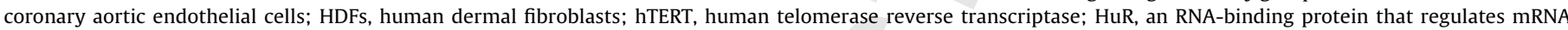

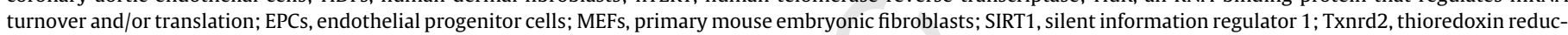

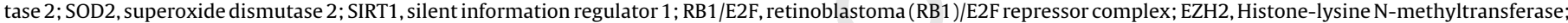
NFIB, nuclear factor I/B; In bold miR common to SA-miRs and inflamma-miRs.

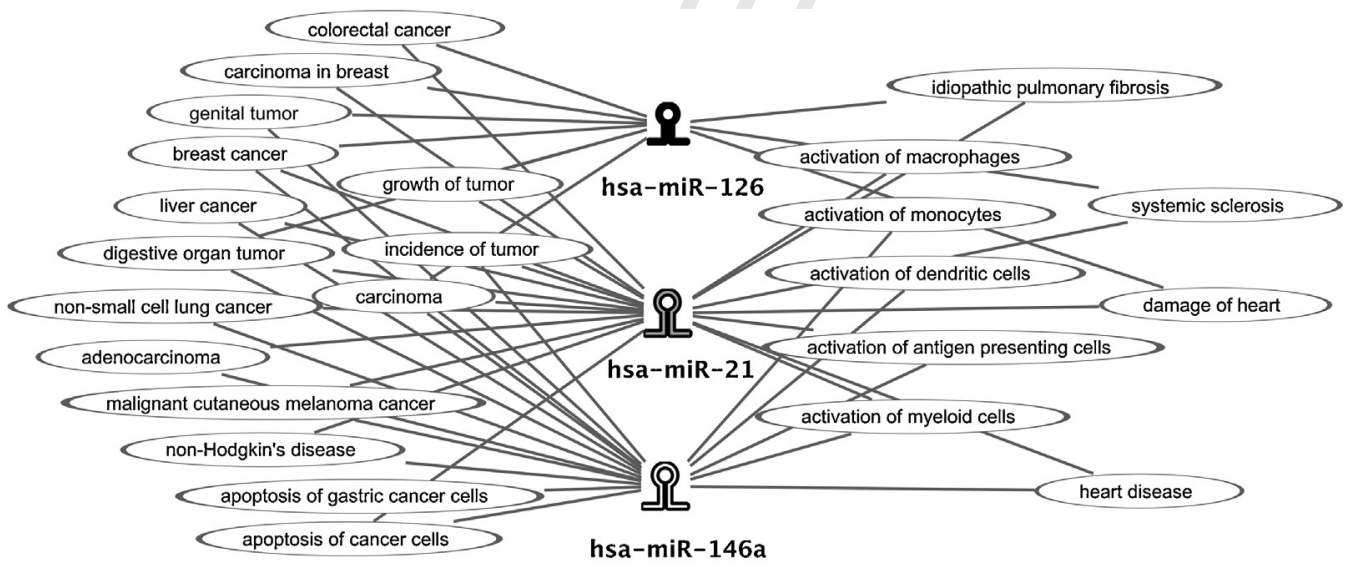

(c) 2000-2012 Ingenuity Systems, Inc. All rights reserved.

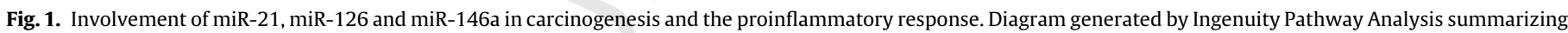
the diseases related to cancer and inflammation where miR-21, -126 and -146a were reported to be involved. Has: human.

suggest that accumulation of dysfunctional circulating endothelial progenitor cells during aging may contribute to miR-21 release into the blood stream. As mentioned above, it has recently been reported that cancer cell-secreted miRs can be internalized via endocytosis by macrophages close to the tumor interface and interact with
TLRs (Fabbri et al., 2012). In particular, miR-21 binds to TLR-8, and induces secretion of proinflammatory cytokines such as tumor necrosis factor (TNF)- $\alpha$ and IL-6.

A clinical model where inflammation and cancer are closely linked is inflammatory bowel disease (IBD), which includes 
Table 3

Main inflammation-associated miRNAs (inflamma-miRs).

\begin{tabular}{|c|c|c|c|c|}
\hline MiRs & Cell types & mRNA targets & Signaling & References \\
\hline MiR-9 & $\begin{array}{l}\text { Polymorphonuclear neutrophils } \\
\text { and monocytes }\end{array}$ & NFK-B1 & TLRs & Bazzoni et al. (2009) \\
\hline MiR-10a & HAECs & HOXA1 & TLRs & Fang et al. (2010) \\
\hline MiR-19a & FLCs & ASK & TLRs & Philippe et al. (2012) \\
\hline \multicolumn{5}{|l|}{ MiR-19b } \\
\hline MiR-20 & FLCs & ASK & TLRs & Philippe et al. (2012) \\
\hline \multirow[t]{3}{*}{ MiR-21 } & Monocytes & TLR-8 & TLRs & Fabbri et al. (2012), Yao et al. \\
\hline & Myofibroblasts, & PDCD4 & TLRs & (2011), Zhou et al. (2011) \\
\hline & HUVECs & $\operatorname{PPAR} \alpha$ & & \\
\hline MiR-29a & Immune cells & TLR-8 & TLRs & Fabbri et al. (2012) \\
\hline MiR-125a & Diffuse large B-cell lymphoma & TNFAIP3 & TLRs & Kim et al. (2012) \\
\hline \multicolumn{5}{|l|}{ MiR-125b } \\
\hline \multirow[t]{4}{*}{ MiR-126 } & ECs, ECs, Human colon-derived & VCAM-1 & Vascular inflammation & Harris et al. (2008), Oglesby et al. \\
\hline & myofibroblasts, Renal & TOM1 & TLRs & (2012), Angel-Morales et al. (2012), \\
\hline & microvascular ECs & VCAM-1 & vascular inflammation & Asgeirsdóttir et al. (2012) \\
\hline & & VCAM-1 & “..." & \\
\hline \multirow[t]{4}{*}{ MiR-146a } & Intestinal epithelial cells, & IRAK-1 & TLRs & Chassin et al. (2012), Iyer et al. \\
\hline & Astrocytes, HUVECs, HUVECs, & IRAK-1 & TLRs & (2012), Olivieri et al. (2012a,b), Liu \\
\hline & Myofibroblasts & IRAK-1 & TLRs & et al. (2012) \\
\hline & & SMAD4 & TGF- $\beta$ & \\
\hline \multirow[t]{3}{*}{ MiR-155 } & MSCs & TAB2 & iNOS & Xu et al. (2013), Nazari-Jahantigh \\
\hline & Macrophages & BCL6 & TLRs & et al. (2012), Sun et al. (2012a) \\
\hline & Macrophages & SOCS1 & TLRs & \\
\hline \multirow[t]{2}{*}{ MiR-181a } & Monocytes and macrophages, & IL-1 ${ }^{\circ}$ & ox-LDL-inflammation & Xie et al. (2013), Wu et al. (2012) \\
\hline & $\begin{array}{l}\text { Cultured bone marrow-derived } \\
\text { DCs }\end{array}$ & c-Fos & responses & \\
\hline MiR-181b & Ecs & Importin- $\alpha 3$ & $\mathrm{NF}-\kappa \mathrm{B}$ & Sun et al. (2012b) \\
\hline \multirow[t]{2}{*}{ MiR-187 } & Primary human monocytes & TNF- $\alpha$ & TLRs & Rossato et al. (2012) \\
\hline & & $\mathrm{I} \kappa \mathrm{B} \zeta$ & & \\
\hline \multirow[t]{2}{*}{ MiR-195 } & Hepatocellular carcinoma Cultured & IKK $\alpha$, TAB3 & TLRs & Ding et al. (2013), Shi et al. (2013) \\
\hline & microglia & ATG14 & $\begin{array}{l}\text { LPS-induction of inflammatory } \\
\text { cytokines }\end{array}$ & \\
\hline MiR-199 & Endometrial stromal cells & IKK $\beta$ & TLRs & Dai et al. (2012) \\
\hline MiR-223 & Macrophages & NLRP3 & Inflammasome & $\begin{array}{l}\text { Ismail et al. (2013), Haneklaus et al. } \\
\text { (2012) }\end{array}$ \\
\hline MiR-517a/c & Cell lines & TNIP1 & TLRs & Olarerin-George et al. (2013) \\
\hline Let-7 & Primary cultured T cells, & TLR-4 & IL-13 & Kumar et al. (2011), Chen et al. \\
\hline Let-7i & Biliary epithelial cells & & TLRs & $(2007)$ \\
\hline
\end{tabular}

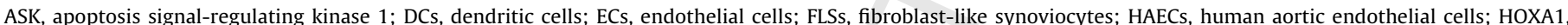

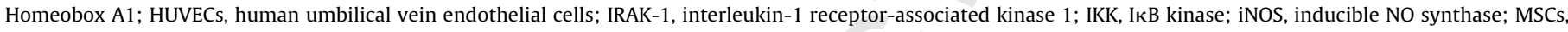

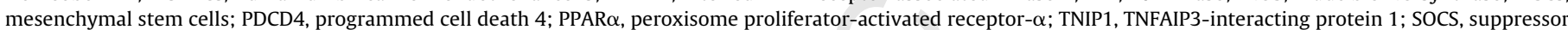

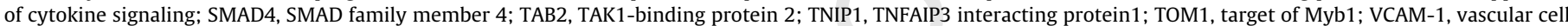
adhesion molecule 1 . In bold miR common to SA-miRs and inflamma-miRs.

Table 4

Q6 Common SA-miRs and inflamma-miRs involved in human malignancies.

\begin{tabular}{|c|c|c|}
\hline MiRs & Cancers & References \\
\hline MiR-9 & NPC & Gao et al. (2013) \\
\hline MiR-19b & DLBCL & Fassina et al. (2012) \\
\hline MiR-20a & DLBCL & Fassina et al. (2012) \\
\hline MiR-21 & Virtually all human cancers & Ma et al. (2013) \\
\hline MiR-29a & Breast cancer & Wang et al. (2013) \\
\hline MiR-126 & NSCLC OSCC & Yang et al. (2012), Jusufović et al. (2012), Sasahira et al. (2012) \\
\hline MiR-146a & NSCLC Gastric cancer & Chen et al. (2013), Yao et al. (2013) \\
\hline MiR-155 & Various carcinomas & He et al. (2013a,b), Yang et al. (2013) \\
\hline MiR-181a & Hematological malignancies & Lin et al. (2013) \\
\hline Let-7 & Various carcinomas & Wang et al. (2012) \\
\hline
\end{tabular}

NSCLC, non-small cell lung cancer; OSCC, oral squamous cell carcinoma; NPC, nasopharyngeal carcinoma; DLBCL, diffuse large B-cell lymphoma.

conditions such as ulcerative colitis and Crohn's colitis. IBD creates the pathological conditions for colorectal cancer (CRC) development (Ludwig et al., 2012); the PDCD4 tumor suppressor gene is involved in colon carcinogenesis and its down-regulation is significantly associated with miR-21 up-regulation. These data document a direct link among miRs, inflammation and CRC development (Okayama et al., 2012).

A recent paper has documented that miR-21 links senescence/replicative life span and angiogenesis in normal human endothelial cells (Dellago et al., 2013). Transfection of early passage endothelial cells with miR-21 resulted in reduced angiogenesis and cell proliferation rates, while its overexpression reduces the replicative life span while stable knockdown extends the replicative life span (Dellago et al., 2013).

\section{MiR-126}

Functional in vitro studies have shown that some miRs are critical for gene expression and endothelial cell function. Mir-126, 
a human miR whose expression has been found to be typical of endothelial cells of capillaries and larger blood vessels, is considered as a master regulator of physiological angiogenesis. It acts on various transcripts by modulating vessel stabilization and maturation (Wang et al., 2008; Sessa et al., 2012). Among its main protein targets, the epidermal growth factor-like domain 7 (EGFL7) gene is involved in cell migration and blood vessel formation (Sun et al., 2010a). MiR-126 has recently been reported to be expressed in hematopoietic stem cells (HSCs) and to play a pivotal role in restraining HSC cell-cycle progression by targeting multiple genes belonging to the phosphatidylinositol 3-kinase (PI3K)/serine/threonine protein kinase AKT/glycogen synthase kinase 3 (PI3K/AKT/GSK3) pathway (Lechman et al., 2012). These data indicate that miR-126 sets a threshold for HSC activation, controlling their pool size. MiR-126 has also been assigned major developmental roles in the heart through activation of survival kinases ERK1/2 and AKT and enhancement of proangiogenic signaling (Shi et al., 2012).

Interestingly, tissue inflammation is critically regulated by miR126 both in vitro and in vivo, via modulation of the expression of cell adhesion proteins such as VCAM-1 (Harris et al., 2008; Asgeirsdóttir et al., 2012; Qin et al., 2011). In a renal inflammation model, the inflammatory challenge unleashed VCAM-1 protein expression in the glomeruli of mice with knockdown of miR-126 function, suggesting that it has a major role in the response of renal microvascular endothelial cells to systemic inflammatory stimuli (Asgeirsdóttir et al., 2012). Accordingly, miR-126 is also deregulated in several disorders characterized by endothelial cell activation in response to systemic inflammatory stimuli, including CVD, diabetes mellitus and inflammatory diseases (Mocharla et al., 2013; Feng et al., 2012; Zampetaki et al., 2012). Interestingly, miR-126 can play an important role in the modulation of inflammatory activity by down-regulating the expression of IKBA, an important inhibitor of the NF- $\kappa B$ signaling pathway (Feng et al., 2012). MiR-126 was also reported to target TOM1 (target of Myb1), which has been shown to interact with toll-interacting proteins in TLR-2/-4 signaling pathways, forming a complex to regulate endosomal trafficking of ubiquitinated proteins (Oglesby et al., 2012).

Altered miR-126 expression has been documented in various cancers, acting as a tumor suppressor or as an oncogene depending on cancer type (Yang et al., 2012; Otsubo et al., 2011).

It is a tumor-suppressor gene in non-small cell lung cancer (NSCLC), repressing the activity of the PI3K-AKT pathway by targeting binding sites in the 3'-UTR region of PI3KR2 mRNA (Yang et al., 2012). Accordingly, NSCLC patients with low miR-126 expression had significantly shorter survival time than those with high miR126 expression (Yang et al., 2012; Jusufović et al., 2012). EGFL7, which is involved in cell responses such as cell migration and blood vessel formation, was identified as miR-126 target in NSCLC cells (Sun et al., 2010b).

In gastric cancer, aberrant over-expression of miR-126 and down-regulation of its target SRY (sex-determining region Y)-box 2 (SOX2) contributes to carcinogenesis (Otsubo et al., 2011). SOX2 is a crucial transcription factor with important roles in growth inhibition through cell cycle arrest and apoptosis. Over-expression of miR-126 was also induced in oral squamous cell carcinoma (OSCC) cells, showing an association with tumor progression, nodal metastasis and vessel density (Sasahira et al., 2012). Interestingly, decreased miR-126 expression strongly correlated with diseasefree survival in OSCC patients (Sasahira et al., 2012).

MiR-126 therefore has a dual role: as an oncosuppressor it inhibits cell proliferation, migration, invasion and survival; as an oncogene it supports cancer progression by promoting blood vessel formation and inflammation at the site of endothelial cell activation (Meister and Schmidt, 2010).

\section{MiR-146a}

It has recently been documented that miR-146a plays a key role as a modulator of the innate immune response (Labbaye and Testa, 2012). Such response is induced through TLRs, and two key adapter molecules in the TLR/NF- $\mathrm{B}$ pathway, TRAF6 and IRAK1, have been identified as miR-146a direct targets (Hou et al., 2009). This suggests a negative regulatory loop where NF- $\mathrm{kB}$ activation up-regulates the miR-146 gene, which upon processing downregulates IRAK1 and TRAF6 to reduce NF- $\kappa$ B activity. Macrophages are the main cell type involved in inflammatory response modulation, mainly through TLR pathway activation. However, our group has recently described increased in vitro expression of miR-146a in human umbilical vein cells (HUVECs) and in aortic and coronary endothelial cells (respectively HAECs and HCAECs) during replicative senescence, thus demonstrating that endothelial cells may play an important role in this process (Olivieri et al., 2012a,b). Similar to macrophages and fibroblasts all three cell types acquired the SASP during replicative senescence despite the fact that miR146a overexpression should physiologically prevent its acquisition studies have shown the pathological relevance of NF- $\mathrm{KB} / \mathrm{miR}-146 \mathrm{a}$ dysregulation in human cancers, including breast and pancreatic cancer, anaplastic thyroid carcinoma, and brain tumors (Bhaumik et al., 2008; Lukiw et al., 2008; Hurst et al., 2009; Li et al., 2010a,b; Pacifico et al., 2010). A contribution of miR-146a deregulation to the development and maintenance of neoplastic processes has been documented by several researchers (Labbaye et al., 2012; Hurst et al., 2009; Li et al., 2010a,b). However, its mechanism of action remains unclear, since both increased and decreased levels have been described in different type of cancers: up-regulation in papillary thyroid carcinoma and cervical, breast, and pancreatic cancer, and down-regulation in prostate cancer (Williams et al., 2008). Since miR-146a participates in a negative feedback loop modulating inflammation, dynamic changes in its expression can be expected in tissues exhibiting different degrees of inflammation.

Interestingly, mice with miR-146a deletion spontaneously developed subcutaneous flank tumors (Zhao et al., 2011). Moreover miR-146a has been reported to suppress metastatic activity (Hwang et al., 2012; Hou et al., 2012). In particular, its up-regulation inhibits cancer cell invasion and metastasis in vitro and in vivo (Hou et al., 2012).

Low miR-146a expression in NSCLC correlated with advanced clinical TNM stages and distant metastasis, whereas high miR-146a levels in the tumor was associated with longer progression-free survival (Chen et al., 2013).

Altogether these findings show that by counteracting the proinflammatory status associated with cellular senescence, miR-146a action by inhibiting tumor development and cancer cell invasion and metastasis.

\subsection{SA-miRs and inflamma-miRs modulation in centenarians}

Cancer incidence and mortality increase exponentially with age, peaking at 80-85 years (Fulop et al., 2010). Quite surprisingly they then decline; accordingly, cancer is relatively uncommon as a disease and as a cause of death among the very old (Pavlidis et al., 2012; Salvioli et al., 2009).

A number of genetic variants predisposing to cancer have been described in healthy centenarians, who also displayed high levels of proinflammatory molecules (Bonafè et al., 1999). These findings seem to contradict the data regarding the interconnection of cancer and inflammation discussed above. To reconcile these conflicting notions it has been proposed that the large amounts of by promoting an anti-inflammatory response. Surprisingly, several can exert anti-inflammatory effects and a general tumor suppressor 
proinflammatory modulators found in centenarians are offset by high levels of anti-inflammatory molecules such as IL-10 and TGF$\beta$ (Vasto et al., 2007; Franceschi et al., 2007). According to another hypothesis the levels of proinflammatory molecules are not critical in themselves, but are more or less dangerous depending on the tissue where they are produced (muscle, adipose tissue, epithelia, etc.) (Salvioli et al., 2012). The latter concept has not yet been tested, since the capacity of different tissues and cells to produce proinflammatory molecules has not been compared in centenarians and young or younger (70-80 year olds) individuals. Similarly, no data are available on the body composition (total amount of fat mass, lean and fat mass ratio, etc.) of centenarians. Nonetheless these individuals seem to be endowed with a resistance to cancer whose underlying mechanisms are still unclear (Bonafè et al., 2011). Given the involvement of miRs in gene expression regulation, a peculiar modulation of their expression might contribute to efficient homeostasis in centenarians. To date only four studies have compared the miR expression profile of centenarians and younger subjects. Although they examined different samples from widely different individuals, i.e. peripheral blood mononuclear cells (PBMCs) from Spanish donors (Serna et al., 2012); B lymphocytes from Ashkenazi Jews (Gombar et al., 2012); plasma from Italian subjects (Olivieri et al., 2012a,b), and whole blood from German individuals (ElSharawy et al., 2012), all four studies found a significant overlap between the miR profiles of centenarians and of young individuals, and a different profile in octogenarians. These findings lend support to the hypothesis that achievement of extreme longevity probably requires a special gene expression regulation (Serna et al., 2012; Olivieri et al., 2012a,b).

Notably, age-related changes have been demonstrated in circulating miR-19b, miR-21, miR-126 and miR-146a, which are among the more common SA-miRs, inflamma-miRs and onco-miRs (Olivieri et al., 2012a,b; our unpublished data). Different miR-19b levels were also reported in PBMCs from octogenarians compared with centenarians and young individuals (Serna et al., 2012).

Significant modulation of miR-20a, -106a, -126 and -155, but not of miR-19b, was reported in whole blood of old subjects (ElSharawy et al., 2012). Interestingly, miR-21 was deregulated in all studies comparing the miR expression profile of centenarians and younger subjects. Significant modulation of miR-21 expression in circulating cells and plasma of centenarians is not surprising to those who advocate that miR-21 lies at the intersection of senescence, inflammation and age-related diseases. However, its expression was significantly higher in PBMCs (Serna et al., 2012) and B lymphocytes (Gombar et al., 2012) from centenarians compared to 20-year olds and octogenarians, whereas its levels in plasma (Olivieri et al., 2012a,b) and whole blood (ElSharawy et al., 2012) were higher in old individuals than in 20-year olds, and higher in octogenarians than in centenarians. Only whole blood showed miR-21 down-regulation in centenarians compared to younger subjects (ElSharawy et al., 2012). Since whole blood is a combination of plasma and PBMCs, such discrepancies could be related to different age-related expression profiles in different biological samples. A direct comparison of the miRNome of whole blood and of serum and hematopoietic subpopulations (e.g. lymphocytes, monocytes and circulating progenitor cells) from subjects with different malignant and nonmalignant diseases is clearly warranted.

\section{5. Conclusions}

MiRs are indisputably opening a new era in the fields of systemic and tissue-specific biomarkers, intercellular and perhaps inter-organ communication mechanisms, and therapeutic strategies. Recent evidence suggests that a number of miRs, including miR-21, -146a and -126, modulate some pathways (e.g. NF- $\mathrm{BB}$ ) related to cellular senescence, inflammation, angiogenesis, physiological aging and development of age-related diseases, including cancer.

Cancer development is largely avoided or delayed in centenarians, subjects who have reached the extreme boundaries of the human life span. In these individuals changes in some miRs involved in cancer, like miR-21, are found both in plasma and leukocytes, further suggesting that a peculiar modulation of this family of small regulators may have a role in preventing development of aggressive cancer disease. It is therefore conceivable that strategies aimed to regulate their expression could help treat a number of age-related conditions (Nana-Sinkam and Croce, 2013; Zhong et al., 2013; Bao et al., 2012; Zhu et al., 2012; Bader, 2012). Given the complexity of in vivo miRNA targeting, including toxicity and target specificity issues, few studies using this approach have reached the clinical trial stage; the most advanced among them currently involves miR-122 targeting in hepatitis C (Machlin et al., 2012).

Modulation of miR-21, -126 and $146 a$ to inhibit cancer cell growth and enhance the cytotoxicity of antitumor agents is being investigated. Some of the miR-21 protein targets modulate TNFrelated apoptosis-inducing ligand (TRAIL) resistance both in human glioblastoma primary cells and in lung cancer cells (Quintavalle et al., 2012). High miR-21 expression levels are needed to maintain the TRAIL-resistant phenotype, making this miR a promising therapeutic target. The combination of miR-21 knockdown with neural precursor cells that secrete a recombinant TRAIL (TNF ligand superfamily, member 10) protein sensitizes gliomas to cytotoxic therapy in vitro and in vivo (Corsten et al., 2007; Leal et al., 2013).

A greater understanding of miR sources and regulation, identification and validation of their target genes and target tissue specificity, and development of safe and effective delivery strategies would considerably enhance their therapeutic potential. Coupling engineered exosomes to nanotechnology would promote the development of immunotherapy approaches and cancer vaccines; eventually, the insertion of specific miRs (or antagomiR) directed against specific cells or tissues could be decisive to achieving therapeutic advances (Tan et al., 2010; Ohno et al., 2013).

Lowering the threshold of cellular senescence through inhibition of CDK regulators has recently been suggested as a new potential approach to cancer treatment (Ling et al., 2012) as has the use of strategies aimed at controlling NF- $\kappa$ B-related inflammation during normal and pathological aging (Osorio et al., 2012). However, modulation of cellular senescence and age-associated inflammation to destroy cancer cells requires further investigation. To do this, in vivo strategies to eliminate senescent cells or the effects of SASP acquisition from cancer-prone tissues need to be developed. MiR-21, miR-146a and miR-126 emerge as promising candidates for the development of new direct and indirect therapeutic strategies against several cancers and other age-related diseases.

\section{Uncited references}

Q4 689

Dommisch et al. (2011), Liu and Ryan (2012), and Yang and Ming (2012).

\section{Conflicts of interest}

The authors have no conflicts of interest.

\section{Acknowledgments}

The authors are grateful to Dr Silvia Modena for the language revision. This work has received funding from the European Union's Seventh Framework Programme (FP7/2007-2011) under grant 
agreement no. 259679 ("IDEAL") and no. 223576 ("MYOAGE") to CF and from the Roberto and Cornelia Pallotti Legacy for Cancer Research (Bologna, Italy) to SS.

\section{References}

Angel-Morales, G., Noratto, G., Mertens-Talcott, S., 2012. Red wine polyphenolics reduce the expression of inflammation markers in human colon-derived CCD 18Co myofibroblast cells: potential role of microRNA-126. Food and Function 3 , 745-752, http://dx.doi.org/10.1039/c2fo10271d.

Angelini, P.D., Fluck, M.F., Pedersen, K., Parra-Palau, J.L., Guiu, M., Bernadó Morales, C. Vicario, R., Luque-García, A. Navalpotro, N.P. Giralt J., Canals, F. Gomis, R.R. Tabernero, J., Baselga, J., Villanueva, J., Arribas, J., 2013. Constitutive HER2 signaling promotes breast cancer metastasis through cellular senescence. Cancer Research 73, 450-458, http://dx.doi.org/10.1158/0008-5472.CAN-12-2301.

Asgeirsdóttir, S.A., van Solingen, C., Kurniati, N.F., Zwiers, P.J., Heeringa, P., van Meurs, M., Satchell, S.C., Saleem, M.A., Mathieson, P.W., Banas, B., Kamps, J.A., Rabelink, T.J., van Zonneveld, A.J., Molema, G., 2012. MicroRNA-126 contributes to renal microvascular heterogeneity of VCAM-1 protein expression in acute inflammation. American Journal of Physiology - Renal Physiology 302, F1630-F1639.

Bader, A.G., 2012. miR-34 - a microRNA replacement therapy is headed to the clinic. Frontiers Genetic 3, 120.

Baek, D., Villen, J., Shin, C., Camargo, F.D., Gygi, S.P., Bartel, D.P., 2008. The impact of microRNAs on protein output. Nature 455, 64-71.

Bai, X.Y., Ma, Y., Ding, R., Fu, B., Shi, S., Chen, X.M., 2011. miR-335 and miR34a promote renal senescence by suppressing mitochondrial antioxidative enzymes. Journal of the American Society of Nephrology 22, 1252-1261, http://dx.doi.org/10.1681/ASN.2010040367.

Bao, B., Li, Y., Ahmad, A., Azmi, A.S., Bao, G., Ali, S., Banerjee, S., Kong, D., Sarkar, F.H., 2012. Targeting CSC-related miRNAs for cancer therapy by natural agents. Current Drug Targets.

Bazzoni, F., Rossato, M., Fabbri, M., Gaudiosi, D., Mirolo, M., Mori, L., Tamassia, N., Mantovani, A., Cassatella, M.A., Locati, M., 2009. Induction and regulatory function of miR-9 in human monocytes and neutrophils exposed to proinflammatory signals. Proceedings of the National Academy of Sciences of the United States of America 106, 5282-5287, http://dx.doi.org/10.1073/pnas.0810909106.

Ben-Neriah, Y., Karin, M., 2011. Inflammation meets cancer, with $\mathrm{NF}-\kappa \mathrm{B}$ as the matchmaker. Nature Immunology 12, 715-723, http://dx.doi.org/10.1038/ni.2060.

Benhamed, M., Herbig, U., Ye, T., Dejean, A., Bischof, O., 2012. Senescence is an endogenous trigger for microRNA-directed transcriptional gene silencing in human cells. Nature Cell Biology 14, 266-275, http://dx.doi.org/10.1038/ncb2443.

Berezikov, E., 2011. Evolution of microRNA diversity and regulation in animals. Nature Reviews Genetics 12, 846-860, http://dx.doi.org/10.1038/nrg3079.

Berman, A.E., Leontieva, O.V., Natarajan, V., McCubrey, J.A., Demidenko, Z.N., Nikiforov, M.A., 2012. Recent progress in genetics of aging, senescence and longevity: focusing on cancer-related genes. Oncotarget 3, 1522-1532.

Bhaumik, D., Scott, G.K., Schokrpur, S., Patil, C.K., Campisi, J., Benz, C.C., 2008. Expression of microRNA-146 suppresses NF-kappaB activity with reduction of metastatic potential in breast cancer cells. Oncogene 27, 5643-5647, http://dx.doi.org/10.1038/onc.2008.171.

Bhaumik, D., Scott, G.K., Schokrpur, S., Patil, C.K., Orjalo, A.V., Rodier, F., Lithgow, G.J. Campisi, J., 2009. MicroRNAs miR-146a/b negatively modulate the senescenceassociated inflammatory mediators IL-6 and IL-8. Aging (Albany NY) 1, 402-411.

Blagosklonny, M.V., 2011. Molecular damage in cancer: an argument for mTORdriven aging. Aging (Albany NY). 3, 1130-1141.

Boldin, M.P., Baltimore, D., 2012. MicroRNAs, new effectors and regulators of NF- $\mathrm{B}$. Immunology Review 246, 205-220, http://dx.doi.org/10.1111/j.1600-065X. 2011.01089.x.

Bonafè, M., Olivieri, F., Mari, D., Baggio, G., Mattace, R., Sansoni, P., De Benedictis, G., De Luca, M., Bertolini, S., Barbi, C., Monti, D., Franceschi, C., 1999. p53 variants predisposing to cancer are present in healthy centenarians. American Journal of Human Genetics 64, 292-295, http://dx.doi.org/10.1086/302196.

Bonafè, M., Storci, G., Franceschi, C., 2012. Inflamm-aging of the stem cell niche: breast cancer as a paradigmatic example: breakdown of the multishell cytokine network fuels cancer in aged people. Bioessays 34, 40-49, http://dx.doi.org/10.1002/bies.201100104.

Borgdorff, V., Lleonart, M.E., Bishop, C.L., Fessart, D., Bergin, A.H., Overhoff, M.G., Beach, D.H., 2010. Multiple microRNAs rescue from Rasinduced senescence by inhibiting p21(Waf1/Cip1). Oncogene 29, 2262-2271, http://dx.doi.org/10.1038/onc.2009.497.

Breving, K., Esquela-Kerscher, A., 2010. The complexities of microRNA regulation: mirandering around the rules. International Journal of Biochemistry and Cell Biology 42, 1316-1329, http://dx.doi.org/10.1016/j.biocel.2009.09.016.

Burton, D.G.A., 2009. Cellular senescence, ageing and disease. Age (Dordr) 31, 1-9.

Campisi, J., 2001. From cells to organisms: can we learn about aging from cells in culture? Experimental Gerontology. 36, 607-618.

Campisi, J., Sedivy, J., 2009. How does proliferative homeostasis change with age? What causes it and how does it contribute to aging? Journal of Gerontology Series A: Biological Sciences and Medical Sciences 64, 164-166.

Campisi, J., 2011. Cellular senescence: putting the paradoxes in perspective. Current Opinion in Genetic Development 21, 107-112, http://dx.doi.org/10.1016/j.gde.2010.10.005.
Cevenini, E., Monti, D., Franceschi, C., 2013. Inflamm-ageing. Current Opinion in Clinical Nutrition \& Metabolic Care 16, 14-20, http://dx.doi.org/10.1097/MCO.0b013e32835ada13.

Chassin, C., Hempel, C., Stockinger, S., Dupont, A., Kübler, J.F., Wedemeyer, J., Vandewalle, A., Hornef, M.W., 2012. MicroRNA-146a-mediated downregulation of IRAK1 protects mouse and human small intestine against ischemia/reperfusion injury. EMBO Molecular Medicine 4, 1308-1319, http://dx.doi.org/10.1002/emmm.201201298.

Chen, X.M., Splinter, P.L., O'Hara, S.P., LaRusso, N.F., 2007. A cellular micro-RNA let-7i, regulates Toll-like receptor 4 expression and contributes to cholangiocyte immune responses against Cryptosporidium parvum infection. Journal of Biological Chemistry 282, 28929-28938.

Chen, G., Umelo, I.A., Lv, S., Teugels, E., Fostier, K., Kronenberger, P., Dewaele, A. Sadones, J., Geers, C., De, Grève, J., 2013. miR-146a inhibits cell growth cell migration and induces apoptosis in non-small cell lung cancer cells. PLoS One 8 e60317, http://dx.doi.org/10.1371/journal.pone.0060317.

Cingarlini, S., Bonomi, M., Corbo, V., Scarpa, A., Tortora, G., 2012. Profiling mTOR pathway in neuroendocrine tumors. Targeted Oncology 7, 183-188, http://dx.doi.org/10.1007/s11523-012-0226-9.

Cloonan, N., Wani, S., Xu, Q., Gu, J., Lea, K., Heater, S., Barbacioru, C., Steptoe, A.L., Martin, H.C., Nourbakhsh, E., Krishnan, K., Gardiner, B., Wang, X., Nones, K., Steen, J.A., Matigian, N.A., Wood, D.L., Kassahn, K.S., Waddell, N., Shepherd, J., Lee, C., Ichikawa, J., McKernan, K., Bramlett, K., Kuersten, S., Grimmond, S.M., 2011. MicroRNAs and their isomiRs function cooperatively to target common biological pathways. Genome Biology 12, R126, http://dx.doi.org/10.1186/gb-2011-12-12-r126.

Collado, M., Gil, J., Efeyan, A., Guerra, C., Schuhmacher, A.J., Barradas, M., Benguría, A., Zaballos, A., Flores, J.M., Barbacid, M., Beach, D., Serrano, M., 2005. Tumour biology: senescence in premalignant tumours. Nature 436, 642.

Collino, F., Deregibus, M.C., Bruno, S., Sterpone, L., Aghemo, G., Viltono, L., Tetta, C., Camussi, G., 2010. Microvesicles derived from adult human bone marrow and tissue specific mesenchymal stem cells shuttle selected pattern of miRNAs. PLoS One 5, e11803, http://dx.doi.org/10.1371/journal.pone.0011803.

Coppè, J.P., Kauser, K., Campisi, J., Beausèjour, C.M., 2006. Secretion of vascular endothelial growth factor by primary human fibroblasts at senescence. Journal of Biological Chemistry 281, 29568-29574, http://dx.doi.org/10.1074/jbc.M603307200.

Coppè, J.P., Patil, C.K., Rodier, F., Krtolica, A., Beausèjour, C.M., Parrinello, S., Hodgson, J.G., Chin, K., Desprez, P.Y., Campisi, J., 2010. A human-like senescence-associated secretory phenotype is conserved in mouse cells dependent on physiological oxygen. PLoS One 5, e9188, http://dx.doi.org/10.1371/journal.pone.0009188.

Corsten, M.F., Miranda, R., Kasmieh, R., Krichevsky, A.M., Weissleder, R., Shah, K. 2007. MicroRNA-21 knockdown disrupts glioma growth in vivo and displays synergistic cytotoxicity with neural precursor cell delivered S-TRAIL in human gliomas. Cancer Research 67, 8994-9000.

Christoffersen, N.R., Shalgi, R., Frankel, L.B., Leucci, E., Lees, M., Klausen, M., Pilpel Y., Nielsen, F.C., Oren, M., Lund, A., 2010. Hp53- independent upregulation of miR-34a during oncogene-induced senescence represses MYC. Cell Death and Difference 17, 236-245, http://dx.doi.org/10.1038/cdd.2009.109.

Dai, L., Gu, L., Di, W., 2012. MiR-199a attenuates endometrial stromal cell invasiveness through suppression of the IKK $\beta / N F-\kappa B$ pathway and reduced interleukin-8 expression. Molecular Human Reproduction 18, 136-145 http://dx.doi.org/10.1093/molehr/gar066.

Dellago, H., Preschitz-Kammerhofer, B., Terlecki-Zaniewicz, L., Schreiner, C., Fortschegger, K., Chang, M.W., Hackl, M., Monteforte, R., Kühnel, H., Schosserer, M., Gruber, F., Tschachler, E., Scheideler, M., Grillari-Voglauer, R., Grillari, J., Wieser, M., 2013. High levels of oncomiR-21 contribute to the senescence induced growth arrest in normal human cells and its knock-down increases the replicative life span. Aging Cell, http://dx.doi.org/10.1111/acel.12069.

Diala, I., Wagner, N., Magdinier, F., Shkreli, M., Sirakov, M., Bauwens, S., SchluthBolard, C., Simonet, T., Renault, V.M., Ye, J., Djerbi, A., Pineau, P., Choi, J. Artandi, S., Dejean, A., Plateroti, M., Gilson, E., 2013. Telomere protection and TRF2 expression are enhanced by the canonical Wnt signalling pathway. EMBO Reports 14, 356-363, http://dx.doi.org/10.1038/embor.2013.16.

Ding, J., Huang, S., Wang, Y., Tian, Q., Zha, R., Shi, H., Wang, Q., Ge, C., Chen, T., Zhao, Y., Liang, L., Li, J., He, X., 2013. Genome-wide screening revealed that miR195 targets the TNF- $\alpha / N F-\kappa B$ pathway by downregulating IKK $\alpha$ and TAB3 in hepatocellular carcinoma. Hepatology, http://dx.doi.org/10.1002/hep.26378.

Dommisch, H., Schaefer, A., Muller-Quernheim, J., Wullich, B., Keck, B., Graf, N., Reichrath, J., Vogel, B., Nebel, A., Jager, S.U., Staehler, P., Amarantos, I., Boisguerin, V., et al., 2011. Toward the blood-borne miRNome of human diseases. Nature Methods 8, 841-884.

Donato, A.J., Black, A.D., Jablonski, K.L., Gano, L.B., Seals, D.R., 2008. Aging is associated with greater nuclear NF kappa B, reduced I kappa B alpha, and increased expression of proinflammatory cytokines in vascular endothelial cells of healthy humans. Aging Cell 7, 805-812, http://dx.doi.org/10.1111/j.1474-9726.2008.00438.x.

ElSharawy, A., Keller, A., Flachsbart, F., Wendschlag, A., Jacobs, G., Kefer, N., Brefort, T., Leidinger, P., Backes, C., Meese, E., Schreiber, S., Rosenstiel, P., Franke, A., Nebel, A., 2012. Genome-wide miRNA signatures of human longevity. Aging Cell 11, 607-616, http://dx.doi.org/10.1111/j.1474-9726.2012.00824.x.

Erusalimsky, J.D., Kurz, D.J., 2005. Cellular senescence in vivo: its relevance in ageing and cardiovascular disease. Experimental Gerontology 40, 634-642, http://dx.doi.org/10.1016/j.exger.2005.04.010.

Fabbri, M., Paone, A., Calore, F., Galli, R., Gaudio, E., Santhanam, R., Lovat, F., Fadda, P., Mao, C., Nuovo, G.J., Zanesi, N., Crawford, M., Ozer, G.H., Wernicke, D., Alder, 
H., Caligiuri, M.A., Nana-Sinkam, P., Perrotti, D., Croce, C.M., 2012. MicroRNAs bind to Toll-like receptors to induce prometastatic inflammatory response. Proceedings of the National Academy of Sciences of the United States of America 109, E2110-E2116.

Fabbri, M., Paone, A., Calore, F., Galli, R., Croce, C.M., 2013. A new role for microRNAs, as ligands of Toll-like receptors. RNA Biology.

Fang, Y., Shi, C., Manduchi, E., Civelek, M., Davies, P.F., 2010. MicroRNA10a regulation of proinflammatory phenotype in athero-susceptible endothelium in vivo and in vitro. Proceedings of the National Academy of Sciences of the United States of America 107, 13450-13455, http://dx.doi.org/10.1073/pnas.1002120107.

Feng, X., Wang, H., Ye, S., Guan, J., Tan, W., Cheng, S., Wei, G., Wu, W., Wu, F., Zhou, Y., 2012. Up-Regulation of microRNA-126 May Contribute to Pathogenesis of Ulcerative Colitis via Regulating NF-kappaB Inhibitor IкB $\alpha$. PLoS One 7, e52782, http://dx.doi.org/10.1371/journal.pone.0052782.

Franceschi, C., Bonafè, M., Valensin, S., Olivieri, F., De Luca, M., Ottaviani, E., De Benedictis, G., 2000. Inflamm-aging. An evolutionary perspective on immunosenescence. Annals of the New York Academy of Sciences 908, 244-254.

Franceschi, C., Capri, M., Monti, D., Giunta, S., Olivieri, F., Sevini, F., Panourgia, M.P., Invidia, L., Celani, L., Scurti, M., Cevenini, E., Castellani, G.C., Salvioli, S., 2007. Inflammaging and anti-inflammaging: a systemic perspective on aging and longevity emerged from studies in humans. Mechanism of Ageing and Development 128, 92-105.

Freund, A., Orjalo, A.V., Desprez, P.Y., Campisi, J., 2010. Inflammatory networks during cellular senescence: causes and consequences. Trends in Molecular Medicine $16,238-246$.

Fulop, T., Kotb, R., Fortin, C.F., Pawelec, G., de Angelis, F., Larbi, A., 2010. Potential role of immunosenescence in cancer development. New York Academy of Sciences $1197,158-165$.

Gombar, S., Jung, H.J., Dong, F., Calder, B., Atzmon, G., Barzilai, N., Tian, X.L., Pothof, J., Hoeijmakers, J.H., Campisi, J., Vijg, J., Suh, Y., 2012. Comprehensive microRNA profiling in B-cells of human centenarians by massively parallel sequencing. BMC Genomics 13, 353.

Gorospe, M., Abdelmohsen, K., 2011. MicroRegulators come of age in senescence. Trends in Genetics 27, 233-241, http://dx.doi.org/10.1016/j.tig.2011.03.005.

Greussing, R., Hackl, M., Charoentong, P., Pauck, A., Monteforte, R., Cavinato, M. Hofer, E., Scheideler, M., Neuhaus, M., Micutkova, L., Mueck, C., Trajanoski, Z., Grillari, J., Jansen-Dürr, P., 2013. Identification of microRNA-mRNA functional interactions in UVB-induced senescence of human diploid fibroblasts. BMC Genomics. 14, 224.

Gao, F., Zhao, Z.L., Zhao, W.T., Fan, Q.R., Wang, S.C., Li, J., Zhang, Y.Q., Shi, J.W., Lin, X.L., Yang, S., Xie, R.Y., Liu, W., Zhang, T.T., Sun, Y.L., Xu, K., Yao, K.T., Xiao, D., 2013. miR-9 modulates the expression of interferon-regulated genes and MHC class I molecules in human nasopharyngeal carcinoma cells. Biochemical and Biophysical Research Communications 431, 610-616, http://dx.doi.org/10.1016/j.bbrc.2012.12.097.

Hackl, M., Brunner, S., Fortschegger, K., Schreiner, C., Micutkova, L., Mück, C., Laschober, G.T., Lepperdinger, G., Sampson, N., Berger, P., HerndlerBrandstetter, D., Wieser, M., Kühnel, H., Strasser, A., Rinnerthaler, M., Breitenbach, M., Mildner, M., Eckhart, L., Tschachler, E., Trost, A., Bauer, J.W., Papak, C., Trajanoski, Z., Scheideler, M., Grillari-Voglauer, R., GrubeckLoebenstein, B., Jansen-Dürr, P., Grillari, J., 2010. miR-17, miR-19b, miR-20a, and miR-106a are down-regulated in human aging. Aging Cell 9, 291-296, http://dx.doi.org/10.1111/j.1474-9726.2010.00549.x.

Hall, M.N., 2008. mTOR-what does it do? Transplantation Proceedings 40, S5-S8, http://dx.doi.org/10.1016/j.transproceed.2008.10.009.

Han, M., Liu, M., Wang, Y., Chen, X., Xu, J., Sun, Y., Zhao, L., Qu, H., Fan, Y., Wu, C., 2012. Antagonism of miR-21 reverses epithelial-mesenchymal transition and cancer stem cell phenotype through AKT/ERK1/2 inactivation by targeting PTEN. PLOS One 7, e39520.

Haneklaus, M., Gerlic, M., Kurowska-Stolarska, M., Rainey, A.A., Pich, D., McInnes, I.B., Hammerschmidt, W., O'Neill, L.A., Masters, S.L., 2012. Cutting edge: miR-223 and EBV miR-BART15 regulate the NLRP3 inflammasome and IL-1 $\beta$ production. Journal of Immunology 189, 3795-3799, http://dx.doi.org/10.4049/jimmunol.1200312.

Hardy, K., Mansfield, L., Mackay, A., Benvenuti, S., Ismail, S., Arora, P., O'Hare, M.J., Jat, P.S., 2005. Transcriptional networks and cellular senescence in human mammary fibroblasts. Molecular Biology of the Cell 16, 943-953.

Harris, T.A., Yamakuchi, M., Ferlito, M., Mendell, J.T., Lowenstein, C.J., 2008. MicroRNA-126 regulates endothelial expression of vascular cell adhesion molecule 1. Proceedings of the National Academy of Sciences of the United States of America 105, 1516-1521.

He, L.Q., Lu, J.H., Yue, Z.Y., 2013a. Autophagy in ageing and ageing-associated diseases. Acta Pharmacologica Sinica, http://dx.doi.org/10.1038/aps.2012.188.

He, J., Zhang, F., Wu, Y., Zhang, W., Zhu, X., He, X., Zhao, Y., Zhang, W., Zhao, Y., 2013b. Prognostic role of microRNA-155 in various carcinomas: results from a meta-analysis. Disease Markers (March), 12.

Hosoda, T., Zheng, H., Cabral-da-Silva, M., Sanada, F., Ide-Iwata, N., Ogórek, B., Ferreira-Martins, J., Arranto, C., D’Amario, D., del Monte, F., Urbanek, K., D’Alessandro, D.A., Michler, R.E., Anversa, P., Rota, M. Kajstura, J., Leri, A., 2011. Human cardiac stem cell differentiation is regulated by a mircrine mechanism. Circulation 123, 1287-1296, http://dx.doi.org/10.1161/CIRCULATIONAHA.110.982918.

Hou, J., Wang, P., Lin, L., Liu, X., Ma, F., An, H., Wang, Z., Cao, X., 2009. MicroRNA146a feedback inhibits RIG-I-dependent Type I IFN production in macrophages by targeting TRAF6, IRAK1, and IRAK2. Journal of Immunology 183, 2150-2158.
Hou, Z., Yin, H., Chen, C., Dai, X., Li, X., Liu, B., Fang, X., 2012. microRNA146a targets the L1 cell adhesion molecule and suppresses the metastatic potential of gastric cancer. Molecular Medicine Reports 6, 501-506, http://dx.doi.org/10.3892/mmr.2012.946.

Hurst, D.R., Edmonds, M.D., Scott, G.K., Benz, C.C., Vaidya, K.S., Welch, D.R. 2009. Breast cancer metastasis suppressor 1 up-regulates miR-146, which suppresses breast cancer metastasis. Cancer Research 69, 1279-1283, http://dx.doi.org/10.1158/0008-5472.CAN-08-3559.

Hwang, S.J., Seol, H.J., Park, Y.M., Kim, K.H., Gorospe, M., Nam, D.H., Kim, H.H., 2012 MicroRNA-146a suppresses metastatic activity in brain metastasis. Molecules and Cells 34, 329-334.

Iyer, A., Zurolo, E., Prabowo, A., Fluiter, K., Spliet, W.G., van Rijen, P.C., Gorter, J.A., Aronica, E., 2012. MicroRNA-146a: a key regulator of astrocyte-mediated inflammatory response. PLoS One 7, e44789, http://dx.doi.org/10.1371/journal.pone.0044789.

Inukai, S., Slack, F., 2013. MicroRNAs and the genetic network in aging. Journal of Molecular Biology, http://dx.doi.org/10.1016/j.jmb.2013.01.023 (pii: S00222836(13)00039-9).

Ismail, N., Wang, Y., Dakhlallah, D., Moldovan, L., Agarwal, K., Batte, K., Shah, P., Wisler, J., Eubank, T.D., Tridandapani, S., Paulaitis, M.E. Piper, M.G., Marsh, C.B., 2013. Macrophage microvesicles induce macrophage differentiation and miR-223 transfer. Blood 121, 984-995, http://dx.doi.org/10.1182/blood-2011-08-374793.

Ito, T., Yagi, S., Yamakuchi, M., 2010. MicroRNA-34a regulation of endothelial senescence. Biochemical and Biophysical Research Communications 398, 735-740, http://dx.doi.org/10.1016/j.bbrc.2010.07.012.

Jeck, W.R., Siebold, A.P., Sharpless, N.E., 2012. Review: a meta-analysis of GWAS studies and age-associated diseases. Aging Cell 11, 727-731, http://dx.doi.org/10.1111/j.1474-9726.2012.00871.x.

Jeyapalan, J.C., Ferreira, M., Sedivy, J.M., Herbig, U., 2007. Accumulation of senescent cells in mitotic tissue of aging primates. Mechanism of Ageing and Development 128, 36-44, http://dx.doi.org/10.1016/j.mad.2006.11.008.

Jong, H.L., Mustafa, M.R., Vanhoutte, P.M., Abubakar, S., Wong, P.F., 2013. MicroRNA 299-3p modulates replicative senescence in endothelial cells. Physiological Genomics.

Jusufović, E., Rijavec, M., Keser, D., Korošec, P., Sodja, E., Iljazović, E., Radojević, Z. Košnik, M., 2012. let-7b and miR-126 are down-regulated in tumor tissue and correlate with microvessel density and survival outcomes in non-small-cell lung cancer. PLoS One 7, e45577, http://dx.doi.org/10.1371/journal.pone.0045577.

Kapoor, P., Deshmukh, R., 2012. VEGF: a critical driver for angiogenesis and subsequent tumor growth: an IHC study. Journal of Oral and Maxillofacial Pathology 16, 330-337, http://dx.doi.org/10.4103/0973-029X.;1; 102478.

Karin, M., 2006. NF-kappaB and cancer: mechanisms and targets. Molecular Carcinogenesis $45,355-361$.

Keller, A., Leidinger, P., Bauer, A., Elsharawy, A., Haas, J., Backes, C., Wendschlag, A., Giese, N., Tjaden, C., Ott, K., Werner, J., Hackert, T., Ruprecht, K., Huwer, H., Huebers, J., Jacobs, G., Rosenstiel, P., Kundu, J.K., Surh, Y.J., 2012. Emerging avenues linking inflammation and cancer. Free Radical Biology and Medicine 52 , 2013-2037, http://dx.doi.org/10.1016/j.freeradbiomed.2012.02.035.

Khokhlov, A.N., 2013. Does aging need its own program, or is the program of development quite sufficient for it? Stationary cell cultures as a tool to search for anti-aging factors. Current Aging Science.

Kim, S.W., Ramasamy, K., Bouamar, H., Lin, A.P., Jiang, D., Aguiar, R.C., 2012. MicroRNAs miR-125a and miR-125b constitutively activate the NF-KB pathway by targeting the tumor necrosis factor alpha-induced protein 3 (TNFAIP3 A20). Proceedings of the National Academy of Sciences of the United States of America 109, 7865-7870, http://dx.doi.org/10.1073/pnas.1200081109.

Kim, J., Kim, J., Kim, D.W., Ha, Y., Ihm, M.H., Kim, H., Song, K., Lee, I., 2010. Wnt5a induces endothelial inflammation via beta-cateninindependent signaling. Journal of Immunology 185, 1274-1282, http://dx.doi.org/10.4049/jimmunol.1000181.

Kim, W., Kim, M., Jho, E.H., 2013. Wnt/ $\beta$-catenin signalling: from plasma membrane to nucleus. Biochemical Journal 450, 9-21, http://dx.doi.org/10.1042/BJ20121284.

Kuilman, T., Michaloglou, C., Vredeveld, L.C., Douma, S., van Doorn, R., Desmet, C.J., Aarden, L.A., Mooi, W.J., Peeper, D.S., 2008. Oncogene-induced senescence relayed by an interleukin-dependent inflammatory network. Cell 133 , 1019-1031, http://dx.doi.org/10.1016/j.cell.2008.03.039.

Kumar, M., Ahmad, T., Sharma, A., Mabalirajan, U., Kulshreshtha, A., Agrawal, A. Ghosh, B., 2011. Let-7 microRNA-mediated regulation of IL-13 and allergic airway inflammation. Journal of Allergy and Clinical Immunology 128, 1077-1085, http://dx.doi.org/10.1016/j.jaci.2011.04.034 e1-10.

Kumarswamy, R., Volkmann, I., Thum, T., 2011. Regulation and function of miRNA21 in health and disease. RNA Biology 8, 706-713.

Labbaye, C., Testa, U., 2012. The emerging role of MIR-146A in the control of hematopoiesis, immune function and cancer. Journal of Hematology \& Oncology.

Laberge, R.M., Awad, P., Campisi, J., Desprez, P.Y., 2012. Epithelial-mesenchymal transition induced by senescent fibroblasts. Cancer Microenvironment 5, 39-44, http://dx.doi.org/10.1007/s12307-011-0069-4.

Leal, J.A., Feliciano, A., Lleonart, M.E., 2013. Stem cell MicroRNAs in senescence and immortalization: novel players in cancer therapy. Medicinal Research Reviews 33, 112-138, http://dx.doi.org/10.1002/med.20246.

Lai, C.C., Lin, P.M., Lin, S.F., Hsu, C.H., Lin, H.C., Hu, M.L., Hsu, C.M., Yang, M.Y., 2013. Altered expression of SIRT gene family in head and neck squamous cell carcinoma. Tumour Biology (Epub ahead of print).$$
955
$$

957
958

$$
\begin{array}{r}
959 \\
960 \\
961
\end{array}
$$

\section{0}

$$
\begin{aligned}
& 961 \\
& 962 \\
& 963
\end{aligned}
$$

$$
\begin{aligned}
& 964 \\
& 965
\end{aligned}
$$

$$
\begin{aligned}
& 964 \\
& 965 \\
& 966 \\
& 967
\end{aligned}
$$

$$
\begin{array}{r}
967 \\
968 \\
969
\end{array}
$$

$$
\begin{aligned}
& 972 \\
& 973 \\
& 974 \\
& 975
\end{aligned}
$$

$$
\begin{aligned}
& 975 \\
& 976 \\
& 977 \\
& 978
\end{aligned}
$$

$$
\begin{aligned}
& 978 \\
& 979 \\
& 980
\end{aligned}
$$

$$
\begin{array}{r}
980 \\
981 \\
982
\end{array}
$$

\section{$\underset{\substack{90 \\ 98}}{98}$}

$$
\begin{aligned}
& 988 \\
& 989 \\
& 990
\end{aligned}
$$

$$
\begin{aligned}
& 991 \\
& 992 \\
& 993
\end{aligned}
$$

$$
\begin{aligned}
& 992 \\
& 993 \\
& 994
\end{aligned}
$$

$$
\begin{aligned}
& 994 \\
& 995 \\
& 996 \\
& 997
\end{aligned}
$$

$$
\begin{aligned}
& 996 \\
& 997 \\
& 998 \\
& 999
\end{aligned}
$$

998
999
1000

$$
\begin{aligned}
& 1000 \\
& 100 \\
& 1002
\end{aligned}
$$

$$
\begin{aligned}
& 1002 \\
& 1003 \\
& 1004 \\
& 1005
\end{aligned}
$$

$$
\begin{aligned}
& 1004 \\
& 1005 \\
& 1006 \\
& 1007
\end{aligned}
$$

100
1007
1008

$$
\begin{aligned}
& 100 \\
& 100 \\
& 101
\end{aligned}
$$

$$
\begin{aligned}
& 1009 \\
& 1010 \\
& 1011 \\
& 1012
\end{aligned}
$$$$
10
$$

1014

101
101
1017
101
1019

$$
\begin{aligned}
& 101 \\
& 102 \\
& 102
\end{aligned}
$$

102
102
102

1022
1023
1024

1024


Lechman, E.R., Gentner, B., van Galen, P., Giustacchini, A., Saini, M., Boccalatte, F.E., Hiramatsu, H., Restuccia, U., Bachi, A., Voisin, V., Bader, G.D., Dick, J.E., Naldini, L., 2012. Attenuation of miR-126 activity expands HSC in vivo without exhaustion. Cell Stem Cell 11, 799-7811.

Lee, B.Y., Han, J.A., Im, J.S., Morrone, A., Johung, K., Goodwin, E.C., Kleijer, W.J., DiMaio, D., Hwang, E.S., 2006. Senescence-associated betagalactosidase is lysosomal beta-galactosidase. Aging Cell 5, 187-195, http://dx.doi.org/10.1111/j.1474-9726.2006.00199.x.

Lena, A.M., Mancini, M., Rivetti di Val Cervo, P., Saintigny, G., Mahé, C., Melino G., Candi, E., 2012. MicroRNA-191 triggers keratinocytes senescence by SATB1 and CDK6 downregulation. Biochemical and Biophysical Research Communications 423, 509-514, http://dx.doi.org/10.1016/j.bbrc.2012.05.153.

Li, G., Luna, C., Qiu, J., Epstein, D.L., Gonzalez, P., 2010a. Modulation of inflammatory markers by miR-146a during replicative senescence in trabecular meshwork cells. Investigative Ophthalmology and Visual Science 51, 2976-2985, http://dx.doi.org/10.1167/iovs.09-4874.

Li, N., Grivennikov, S.I., Karin, M., 2011. The unholy trinity: inflammation, cytokines, and STAT3 shape the cancer microenvironment. Cancer Cell 19, 429-431, http://dx.doi.org/10.1016/j.ccr.2011.03.018.

Li, Y., Vandenboom 2nd, T.G., Wang, Z., Kong, D., Ali, S., Philip, P.A., Sarkar, F.H., 2010b. miR-146a suppresses invasion of pancreatic cancer cells. Cancer Research 70, 1486-1495, http://dx.doi.org/10.1158/0008-5472.CAN-09-2792.

Li, G., Yu, M., Lee, W.W., Tsang, M., Krishnan, E., Weyand, C.M., Goronzy, J.J., 2012a. Decline in miR-181a expression with age impairs $\mathrm{T}$ cell receptor sensitivity by increasing DUSP6 activity. Nature Medicine 18, 1518-1524, http://dx.doi.org/10.1038/nm.2963.

Li, X.D., Chen, J., Ruan, C.C., Zhu, D.L., Gao, P.J., 2012b. Vascular endothelial growth factor-induced osteopontin expression mediates vascular inflammation and neointima formation via Flt-1 in adventitial fibroblasts. Arteriosclerosis, Thrombosis, and Vascular Biology 32, 2250-2258, http://dx.doi.org/10.1161/ATVBAHA.112.255216.

Lin, H., Hua, F., Hu, Z.W., 2012a. Autophagic flux, supported by toll-like receptor 2 activity, defends against the carcinogenesis of hepatocellular carcinoma. Autophagy 8, 1859-1861, http://dx.doi.org/10.4161/auto.22094.

Lin, S., Yang, J., Elkahloun, A.G., Bandyopadhyay, A., Wang, L., Cornell, J.E., Yeh, I.T., Agyin, J., Tomlinson, G., Sun, L.Z., 2012b. Attenuation of TGF$\beta$ signaling suppresses premature senescence in a p21-dependent manner and promotes oncogenic Ras-mediated metastatic transformation in human mammary epithelial cells. Molecular Biology of the Cell 23, 1569-1581, http://dx.doi.org/10.1091/mbc.E11-10-0849.

Lin, S., Pan, L., Guo, S., Wu, J., Jin, L., Wang, J.C., Wang, S., 2013. Prognostic role of microRNA-181a/b in hematological malignancies: a meta-analysis. PLoS One 8, e59532, http://dx.doi.org/10.1371/journal.pone.0059532.

Ling, H., Samarasinghe, S., Kulasiri, D., 2012. Computational experiments reveal the efficacy of targeting CDK2 and CKIs for significantly lowering cellular senescence bar for potential cancer treatment. Biosystems, http://dx.doi.org/10.1016/j.biosystems.2012.12.001.

Lisanti, M.P., Martinez-Outschoorn, U.E., Pavlides, S., Whitaker-Menezes, D., Pestell, R.G., Howell, A., Sotgia, F., 2011. Accelerated aging in the tumor microenvironment: connecting aging, inflammation and cancer metabolism with personalized medicine. Cell Cycle 10, 2059-2063.

Liu, E.Y., Ryan, K.M., 2012. Autophagy and cancer - issues we need to digest. Journal of Cell Science 125, 2349-2358, http://dx.doi.org/10.1242/jcs.093708.

Liu, L.Z., Li, C., Chen, Q., Jing, Y., Carpenter, R., Jiang, Y., Kung, H.F., Lai, L., Jiang, B.H., 2011. MiR-21 induced angiogenesis through AKT and ERK activation and HIF-1 $\alpha$ expression. PLoS One 6, e19139.

Liu, Z., Lu, C.L., Cui, L.P., Hu, Y.L., Yu, Q., Jiang, Y., Ma, T., Jiao, D.K., Wang, D., Jia, C.Y., 2012. MicroRNA-146a modulates TGF- $\beta 1$-induced phenotypic differentiation in human dermal fibroblasts by targeting SMAD4. Archives of Dermatology Research 304, 195-202, http://dx.doi.org/10.1007/s00403-011-1178-0.

Lovat, F., Valeri, N., Croce, C.M., 2011. MicroRNAs in the pathogenesis of cancer. Seminars in Oncology 38, 724-733, http://dx.doi.org/10.1053/j.seminoncol.2011.08.006.

Ludwig, K., Fassan, M., Mescoli, C., Pizzi, M., Balistreri, M., Albertoni, L., Pucciarelli, S., Scarpa, M., Sturniolo, G.C., Angriman, I., Rugge, M., 2012. PDCD4/miR-21 dysregulation in inflammatory bowel disease-associated carcinogenesis. Virchows Archiv.

Lukiw, W.J., Zhao, Y., Cui, J.G., 2008. An NF-kappaB-sensitive micro RNA146a-mediated inflammatory circuit in Alzheimer disease and in stressed human brain cells. Journal of Biological Chemistry 283, 31315-31322, http://dx.doi.org/10.1074/jbc.M805371200.

Ma, X., Becker Buscaglia, L.E., Barker, J.R., Li, Y., 2011. MicroRNAs in NFkappaB signaling. Journal of Molecular and Cellular Biology 3, 159-166, http://dx.doi.org/10.1093/jmcb/mjr007.

Ma, X., Choudhury, S.N., Hua, X., Dai, Z., Li, Y., 2013. Interaction of the oncogenic miR-21 microRNA and the p53 tumor suppressor pathway. Carcinogenesis.

Machlin, E.S., Sarnow, P., Sagan, S.M., 2012. Combating hepatitis C virus by targeting microRNA-122 using locked nucleic acids. Current Gene Therapy 12, 301-306.

Mancini, M., Saintigny, G., Mahé, C., Annicchiarico-Petruzzelli, M., Melino, G., Candi, E., 2012. MicroRNA-152 and -181a participate in human dermal fibroblasts senescence acting on cell adhesion and remodeling of the extra-cellular matrix. Aging (Albany NY) 4, 843-853.

Marasa, B.S., Srikantan, S., Martindale, J.L., Kim, M.M., Lee, E.K., Gorospe, M., Abdelmohsen, K., 2010. MicroRNA profiling in human diploid fibroblasts uncovers miR-519 role in replicative senescence. Aging (Albany NY) 2, 333-343.
Marchetti, B., Pluchino, S., 2013. Wnt your brain be inflamed? Yes, it Wnt! Trends in Molecular Medicine 19, 144-156, http://dx.doi.org/10.1016/j.molmed.2012.12.001

Martinez, I. Cazalla, D. Almstead, L.L. Steitz, J.A. DiMaio, D., 2011a. miR-29 and miR-30 regulate B-Myb expression during cellular senescence. Proceedings of the National Academy of Sciences of the United States of America 108, 522-527. http://dx.doi.org/10.1073/pnas.1017346108.

Martinez, I., Almstead, L.L., DiMaio, D., 2011b. MicroRNAs and senescence. Aging (Albany NY) 3, 77-78.

Meister, J., Schmidt, M.H., 2010. miR-126 and miR-126*: new players in cancer Scientific World Journal 10, 2090-2100.

Menghini, R., Casagrande, V., Cardellini, M., Martelli, E., Terrinoni, A., Amati, F., Vasa-Nicotera, M., Ippoliti, A., Novelli, G., Melino, G., Lauro, R., Federici, M., 2009. MicroRNA 217 modulates endothelial cell senescence via silent information regulator 1 . Circulation 120, 1524-1532, http://dx.doi.org/10.1161/CIRCULATIONAHA.109.864629.

Merline, R., Moreth, K., Beckmann, J., Nastase, M.V., Zeng-Brouwers, J., Tralhão, J.G., Lemarchand, P., Pfeilschifter, J., Schaefer, R.M., Iozzo, R.V., Schaefer, L., 2011. Signaling by the matrix proteoglycan decorin controls inflammation and cancer through PDCD4 and MicroRNA-21. Science Signaling 4, ra75.

Michaloglou, C., Vredeveld, L.C., Soengas, M.S., Denoyelle, C., Kuilman, T., van der Horst, C.M., Majoor, D.M., Shay, J.W., Mooi, W.J., Peeper, D.S., 2005. BRAFE600-associated senescence-like cell cycle arrest of human naevi. Nature 436, 720-724.

Minamino, T., Yoshida, T., Tateno, K., Miyauchi, H., Zou, Y., Toko, H., Komuro, I., 2003. Circulation 108, 2264-2269.

Mitomo, S., Maesawa, C., Ogasawara, S., Iwaya, T., Shibazaki, M., Yashima-Abo, A., Kotani, K., Oikawa, H., Sakurai, E., Izutsu, N., Kato, K., Komatsu, H., Ikeda, K., Wakabayashi, G., Masuda, T., 2008. Downregulation of miR-138 is associated with overexpression of human telomerase reverse transcriptase protein in human anaplastic thyroid carcinoma cell lines. Cancer Science 99, 280-286, http://dx.doi.org/10.1111/j.1349-7006.2007.00666.x.

Mocharla, P., Briand, S., Giannotti, G., Dörries, C., Jakob, P., Paneni, F., Lüscher, T., Landmesser, U., 2013. AngiomiR-126 expression and secretion from circulating $\mathrm{CD} 34+$ and CD14+ PBMCs: role for proangiogenic effects and alterations in type 2 diabetics. Blood 121, 226-236, http://dx.doi.org/10.1182/blood-2012-01-407106.

Morris, B.J., 2013. Seven sirtuins for seven deadly diseases ofaging. Free Radical Biology and Medicine 56, 133-171, http://dx.doi.org/10.1016/j.freeradbiomed.2012.10.525.

Nana-Sinkam, S.P., Croce, C.M., 2013. Clinical Applications for microRNAs in Cancer. Clin Pharmacology Theraphy 93, 98-104, http://dx.doi.org/10.1038/clpt.2012.192.

Nazari-Jahantigh, M., Wei, Y., Noels, H., Akhtar, S., Zhou, Z., Koenen, R.R., Heyll, K., Gremse, F., Kiessling, F., Grommes, J., Weber, C., Schober, A., 2012. MicroRNA-155 promotes atherosclerosis by repressing Bcl6 in macrophages. Journal of Clinical Investigation 122, 4190-4202, http://dx.doi.org/10.1172/JCI61716.

Neilsen, C.T., Goodall, G.J., Bracken, C.P., 2012. IsomiRs - the overlooked repertoire in the dynamic microRNAome. Trends in Genetics 28, 544-549, http://dx.doi.org/10.1016/j.tig.2012.07.005.

Olarerin-George, A.O., Anton, L., Hwang, Y.C., Elovitz, M.A., Hogenesch, J.B., 2013. A functional genomics screen for microRNA regulators of NF-kappaB signaling. BMC Biology 11, 19.

Olivieri, F., Lazzarini, R., Recchioni, R., Marcheselli, F., Rippo, M.R., Di Nuzzo, S., Albertini, M.C., Graciotti, L., Babini, L., Mariotti, S., Spada, G., Abbatecola, A.M., Antonicelli, R., Franceschi, C., Procopio, A.D., 2012a. MiR-146a as marker of senescence-associated pro-inflammatory status in cells involved in vascular remodelling. Age (Dordr).

Olivieri, F., Spazzafumo, L., Santini, G., Lazzarini, R., Albertini, M.C., Rippo, M.R. Galeazzi, R., Abbatecola, A.M., Marcheselli, F., Monti, D., Ostan, R., Cevenini, E., Antonicelli, R., Franceschi, C., Procopio, A.D., 2012b. Age-related differences in the expression of circulating microRNAs: miR-21 as a new circulating marker of inflammaging. Mechanism of Ageing and Development 133, 675-685, http://dx.doi.org/10.1016/j.mad.2012.09.004.

Olivieri, F., Rippo, M.R., Prattichizzo, F., Babini, L., Graciotti, L., Recchioni, R., Procopio, A.D., 2013. Toll like receptor signaling in "inflammaging": microRNA as new players. Immunity and Ageing 10, 11.

Osorio, F.G., López-Otín, C., Freije, J.M., 2012. NF-кB in premature aging. Aging (Albany NY) 4, 726-727.

Otsubo, T., Akiyama, Y., Hashimoto, Y., Shimada, S., Goto, K., Yuasa, Y., 2011. MicroRNA-126 inhibits SOX2 expression and contributes to gastric carcinogenesis. PLoS One 6, e16617.

Pacifico, F., Crescenzi, E., Mellone, S., Iannetti, A., Porrino, N., Liguoro, D., Moscato, F., Grieco, M., Formisano, S., Leonardi, A., 2010. Nuclear factor- $\{$ kappa $\}$ B contributes to anaplastic thyroid carcinomas through up-regulation of miR146a. Journal of Clinical Endocrinology and Metabolism 95, 1421-1430, http://dx.doi.org/10.1210/jc.2009-1128.

Paik, J.H., Jang, J.Y., Jeon, Y.K., Kim, W.Y., Kim, T.M., Heo, D.S., Kim, C.W. 2011. MicroRNA-146a downregulates NFKB activity via targeting TRAF6 and functions as a tumor suppressor having strong prognostic implications in NK/T cell lymphoma. Clinical Cancer Research 17, 4761-4771, http://dx.doi.org/10.1158/1078-0432.CCR-11-0494.

Park, S., Kang, S., Min, K.H., Woo Hwang, K, Min, H., 2012. Age-associated changes in microRNA expression in bone marrow derived dendritic cells. Immunologica Investigations 42, 179-190, http://dx.doi.org/10.3109/08820139.2012.717328. 
Park, K., Kim, K.B., 2013. miRTar hunter: a prediction system for identifying human microRNA target sites. Molecules and Cells 35, 195-201, http://dx.doi.org/10.1007/s10059-013-2165-4.

Parvani, J.G., Taylor, M.A., Schiemann, W.P., 2011. Noncanonical TGF- $\beta$ signaling during mammary tumorigenesis. Journal of Mammary Gland Biology and Neoplasia 16, 127-146, http://dx.doi.org/10.1007/s10911-011-9207-3.

Pavlidis, N., Stanta, G., Audisio, R.A., 2012. Cancer prevalence and mortality in centenarians: a systematic review. Critical Reviews in Oncology/Hematology 83, $145-152$.

Philippe, L., Alsaleh, G., Pichot, A., Ostermann, E., Zuber, G., Frisch, B., Sibilia, J., Pfeffer, S., Bahram, S., Wachsmann, D., Georgel, P., 2012. MiR-20a regulates ASK1 expression and TLR4-dependent cytokine release in rheumatoid fibroblast-like synoviocytes. Annals of Rheumatic Diseaes.

Qin, B., Yang, H., Xiao, B., 2011. Role of microRNAs in endothelial inflammation and senescence. Molecular Biology Reports 39, 4509-4518.

Quinn, S.R., O'Neill, L.A., 2011. A trio of microRNAs that control Tolllike receptor signaling. International Immunology 23, 421-425, http://dx.doi.org/10.1093/intimm/dxr034.

Quintavalle, C., Donnarumma, E., Iaboni, M., Roscigno, G., Garofalo, M., Romano, G., Fiore, D., De Marinis, P., Croce, C.M., Condorelli, G., 2012. Effect of miR21 and miR-30b/c on TRAIL-induced apoptosis in glioma cells. Oncogene, http://dx.doi.org/10.1038/onc.2012.410.

Raitoharju, E., Lyytikäinen, L.P., Levula, M., Oksala, N., Mennander, A., Tarkka, M., Klopp, N., Illig, T., Kähönen, M., Karhunen, P.J., Laaksonen, R., Lehtimäki, T., 2011. miR-21, miR-210, miR-34a, and miR-146a/b are up-regulated in human atherosclerotic plaques in the Tampere Vascular Study. Atherosclerosis 219, 211-217.

Ren, J.L., Pan, J.S., Lu, Y.P., Sun, P., Han, J., 2009. Inflammatory signaling and cellular senescence. Cell Signaling 21, 378-383, http://dx.doi.org/10.1016/j.cellsig.2008.10.011.

Rippe, C., Blimline, M., Magerko, K.A., Lawson, B.R., LaRocca, T.J., Donato, A.J., Seals, D.R., 2012. MicroRNA changes in human arterial endothelial cells with senescence: relation to apoptosis, eNOS and inflammation. Experimental Gerontology 47, 45-51, http://dx.doi.org/10.1016/j.exger.2011.10.004.

Rodier, F., Campisi, J., 2011. Four faces of cellular senescence. Journal of Cell Biology 192, 547-556.

Rossato, M., Curtale, G., Tamassia, N., Castellucci, M., Mori, L., Gasperini, S., Mariotti, B., De Luca, M., Mirolo, M., Cassatella, M.A., Locati, M., Bazzoni, F., 2012. IL-10-induced microRNA-187 negatively regulates TNF- $\alpha$, IL-6, and IL12 p40 production in TLR4-stimulated monocytes. Proceedings of the National Academy of Sciences of the United States of America 109, E3101-E3110, http://dx.doi.org/10.1073/pnas.1209100109.

Salminen, A., Kaarniranta, K., Kauppinen, A., 2012. Inflammaging: disturbed interplay between autophagy and inflammasomes. Aging (Albany NY) 4, 166-175.

Salminen, A., Kauppinen, A., Kaarniranta, K., 2012a. Emerging role of NF- $\kappa$ B signaling in the induction of senescence-associated secretory phenotype (SASP). Cellular Signalling 24, 835-845, http://dx.doi.org/10.1016/j.cellsig.2011.12.006.

Salvioli, S., Monti, D., Lanzarini, C., Conte, M., Pirazzini, C., Bacalini, M.G., Garagnanin, P., Giuliani, C., Fontanesi, E., Ostan, R., Bucci, L., Sevini, F., Lukas Yani, S., Barbieri, A., Lomartire, L., Borelli, V., Vianello, D., Bellavista, E., Martucci, M., Cevenini, E., Pini, E., Scurti, M., Biondi, F., Santoro, A., Capri, M., Franceschi, C., 2012. Immune system, cell senescence, aging and longevity - inflamm-aging reappraised. Current Pharmaceutical Design (Epub ahead of print).

Salvioli, S., Capri, M., Bucci, L., Lanni, C., Racchi, M., Uberti, D., Memo, M., Mari, D., Govoni, S., Franceschi, C., 2009. Why do centenarians escape or postpone cancer? The role of IGF-1, inflammation and p53. Cancer Immunology Immunotherapy 58, 1909-1917.

Sasahira, T., Kurihara, M., Bhawal, U.K., Ueda, N., Shimomoto, T., Yamamoto, K., Kirita, T., Kuniyasu, H., 2012. Downregulation of miR-126 induces angiogenesis and lymphangiogenesis by activation of VEGF-A in oral cancer. British Journal of Cancer 107, 700-706, http://dx.doi.org/10.1038/bjc.2012.330.

Saunders, L.R., Sharma, A.D., Tawney, J., Nakagawa, M., Okita, K., Yamanaka, S., Willenbring, H., Verdin, E., 2010. miRNAs regulate SIRT1 expression during mouse embryonic stem cell differentiation and in adult mouse tissues. Aging (Albany NY) 2, 415-431.

Schetter, A.J., Heegaard, N.H., Harris, C.C., 2010. Inflammation and cancer: interweaving microRNA, free radical, cytokine and p53 pathways. Carcinogenesis 31, 37-49, http://dx.doi.org/10.1093/carcin/bgp272.

Schetter, A.J., Nguyen, G.H., Bowman, E.D., Mathé, E.A., Yuen, S.T., Hawkes, J.E., Croce, C.M., Leung, S.Y., Harris, C.C., 2009. Association of inflammationrelated and microRNA gene expression with cancer-specific mortality of colon adenocarcinoma. Clinical Cancer Research 15, 5878-5887, http://dx.doi.org/10.1158/1078-0432.CCR-09-0627.

Senturk, S., Mumcuoglu, M., Gursoy-Yuzugullu, O., Cingoz, B., Akcali, K.C., Ozturk, M., 2010. Transforming growth factor-beta induces senescence in hepatocellular carcinoma cells and inhibits tumor growth. Hepatology 52, 966-974, http://dx.doi.org/10.1002/hep.23769.

Serna, E., Gambini, J., Borras, C., Mohammed, K., Belenguer, A., Sanchis, P., Avellana, J.A., Rodriguez-Mañas, L., Viña, J., 2012. Centenarians, but not octogenarians, up-regulate the expression of microRNAs. Scientific Report 2, 961, http://dx.doi.org/10.1038/srep00961.

Sessa, R., Seano, G., di Blasio, L., Gagliardi, P.A., Isella, C., Medico, E., Cotelli, F., Bussolino, F., Primo, L., 2012. The miR-126 regulates angiopoietin-1 signaling and vessel maturation by targeting p $85 \beta$. Biochimica et Biophysica Acta 1823, 1925-1935, http://dx.doi.org/10.1016/j.bbamcr.2012.07.011.
Shi, H., Chen, L., Wang, H., Zhu, S., Dong, C., Webster, K.A., Wei, J., 2012. Synergistic induction of miR-126 by hypoxia and HDAC inhibitors in cardiac myocytes. Biochemical and Biophysical Research Communications 430, $827-832$.

Shi, G., Shi, J., Liu, K., Liu, N., Wang, Y., Fu, Z., Ding, J., Jia, L., Yuan, W., 2013. Increased miR-195 aggravates neuropathic pain by inhibiting autophagy following peripheral nerve injury. Glia 61, 504-512, http://dx.doi.org/10.1002/glia.22451.

Sikora, E., Arendt, T., Bennett, M., Narita, M., 2011. Impact of cellular senescence signature on ageing research. Ageing Research Review 10 (1), 46-152, http://dx.doi.org/10.1016/j.arr.2010.10.002.

Sun, X., Icli, B., Wara, A.K., Belkin, N., He, S., Kobzik, L., Hunninghake, G.M., Vera, M.P., Registry, M.I.C.U., Blackwell, T.S., Baron, R.M., Feinberg, M.W., 2012a. MicroRNA-181b regulates NF- $\mathrm{B}$ B-mediated vascular inflammation. Journal of Clinical Investigation 122, 1973-1990, http://dx.doi.org/10.1172/JCI61495.

Sun, Y., Cai, J., Ma, F., Lü, P., Huang, H., Zhou, J., 2012b. miR-155 mediates suppressive effect of progesterone on TLR3, TLR4-triggered immune response. Immunology Letters 146, 25-30, http://dx.doi.org/10.1016/j.imlet.2012.04.007.

Sun, Y.Q., Zhang, F., Bai, Y.F., Guo, L.L., 2010a. "miR-126 modulates the expression of epidermal growth factor-like domain 7 in human umbilical vein endothelial cells in vitro". Nan fang yi ke da xue xue bao (Journal of Southern Medical University) 30, 767-770 (PMID 20423846).

Sun, Y., Bai, Y., Zhang, F., Wang, Y., Guo, Y., Guo, L., 2010b. miR-126 inhibits non-small cell lung cancer cells proliferation by targeting EGFL7. Biochemical and Biophysical Research Communications 391, 1483-1489, http://dx.doi.org/10.1016/j.bbrc.2009.12.098.

Tacutu, R., Budovsky, A., Yanai, H., Fraifeld, V.E., 2011. Molecular links between cellular senescence, longevity and age-related diseases - a systems biology perspective. Aging (Albany NY) 3, 1178-1191.

Tacutu, R., Budovsky, A., Wolfson, M., Fraifeld, V.E., 2010. MicroRNA-regulated protein-protein interaction networks: how could they help in searching for pro-longevity targets? Rejuvenation Research 13, 373-377, http://dx.doi.org/10.1089/rej.2009.0980.

Tan, A., De La Pena, H., Seifalian, A.M., 2010. The application of exosomes as a nanoscale cancer vaccine. International Journal of Nanomedicine 5, 889-900.

Tetè, S., Tripodi, D., Rosati, M., Conti, F., Maccauro, G., Saggini, A., Salini, V., Cianchetti, E., Caraffa, A., Antinolfi, P., Toniato, E., Castellani, M.L., Pandolfi, F., Frydas, S., Conti, P., Theoharides, T.C., 2012. Endothelial cells, cholesterol, cytokines, and aging. International Journal of Immunopathology and Pharmacology 25, 355-363.

Toledano, H., 2012. The role of the heterochronic microRNA let7 in the progression of aging. Experimental Gerontology, http://dx.doi.org/10.1016/j.exger.2012.08.006 (pii: S0531-5565(12)00231-8).

Tsaousi, A., Mill, C., George, S.J., 2011. The Wnt pathways in vascular disease: lessons from vascular development. Current Opinion in Lipidology 22, 350-357, http://dx.doi.org/10.1097/MOL. 0b013e32834 aa701.

Tzatsos, A., Paskaleva, P., Lymperi, S., Contino, G., Stoykova, S., Chen, Z., Wong, K.K. Bardeesy, N., 2011. Lysine-specific demethylase 2B (KDM2B)-let-7-enhancer of zester homolog $2(\mathrm{EZH} 2)$ pathway regulates cell cycle progression and senescence in primary cells. Journal of Biological Chemistry 286, 33061-33069, http://dx.doi.org/10.1074/jbc.M111.257667.

Varecza, Z., Kvell, K., Talabér, G., Miskei, G., Csongei, V., Bartis, D., Anderson, G., Jenkinson, E.J., Pongracz, J.E., 2011. Multiple suppression pathways of canonical Wnt signalling control thymic epithelial senescence. Mech Ageing Dev. 132, 249-256 http://dx.doi.org/10.1016/j.mad.2011.04.007.

Vasto, S., Candore, G., Balistreri, C.R., Caruso, M., Colonna-Romano, G., Grimaldi, M.P., Listi, F., Nuzzo, D., Lio, D., Caruso, C., 2007. Inflammatory networks in ageing, age-related diseases and longevity. Mechanism of Ageing and Development 128, 83-91.

Vaz, C., Mer, A.S., Bhattacharya, A., Ramaswamy, R., 2011. MicroRNAs modulate the dynamics of the NF- $\kappa$ B signaling pathway. PLoS One 6, e27774 http://dx.doi.org/10.1371/journal. pone.0027774.

Wahlgren, J., De, L., Karlson, T., Brisslert, M., Vaziri Sani, F., Telemo, E., Sunner hagen, P., Valadi, H., 2012. Plasma exosomes can deliver exogenous short interfering RNA to monocytes and lymphocytes. Nucleic Acids Research 40, e130.

Wang, S., Aurora, A.B., Johnson, B.A., Qi, X., McAnally, J., Hill, J.A., Richardson, J.A., Bassel-Duby, R., Olson, E.N., 2008. "The endothelial-specific microRNA miR-126 governs vascular integrity and angiogenesis". Developmental Cell 15 , 261-271, http://dx.doi.org/10.1016/j.devcel.2008.07.002.PMC 2685763, PMID: 18694565.

Wang, C., Jurk, D., Maddick, M., Nelson, G., Martin-Ruiz, C., von Zglinicki, T., 2009 DNA damage response and cellular senescence in tissues of aging mice. Aging Cell 8, 311-323, http://dx.doi.org/10.1111/j.1474-9726.2009.00481.x.

Wang, M., Cheng, Z., Tian, T., Chen, J., Dou, F., Guo, M., Cong, Y.S., 2011 Differential expression of oncogenic miRNAs in proliferating and senescent human fibroblasts. Molecular and Cellular Biochemistry 352, 271-279, http://dx.doi.org/10.1007/s11010-011-0763-z.

Wang, Y., Zhang, X., Li, H., Yu, J., Ren, X., 2013. The role of miRNA29 family in cancer. European Journal of Cell Biology 92, 123-128, http://dx.doi.org/10.1016/j.ejcb.2012.11.004.

Wang, Y., Hu, X., Greshock, J., Shen, L., Yang, X., Shao, Z., Liang, S., Tanyi, J.L., Sood, A.K., Zhang, L., 2012. Genomic DNA copy-number alterations of the let-7 family in human cancers. PLoS One 7, e44399, http://dx.doi.org/10.1371/journal.pone.0044399.

Williams, A.E., Perry, M.M., Moschos, S.A., Larner-Svensson, H.M., Lindsay, M.A., 2008. Role of miRNA-146a in the regulation of the innate immune 
response and cancer. Biochemical Society Transactions 36, 1211-1215. http://dx.doi.org/10.1042/BST0361211.

Wu, S., Hultquist, A., Hydbring, P., Cetinkaya, C., Oberg, F., Larsson, L.G., 2009. TGF-beta enforces senescence in Myc-transformed hematopoietic tumor cells through induction of Mad1 and repression of Myc activity. Experimental Cell Research 315, 3099-3111, http://dx.doi.org/10.1016/j.yexcr.2009.09.009.

Wu, C., Gong, Y., Yuan, J., Zhang, W., Zhao, G., Li, H., Sun, A., KaiHu, Zou, Y., Ge, J., 2012. microRNA- 181a represses ox-LDL-stimulated inflammatory response in dendritic cell by targeting c-Fos. Journal of Lipid Research 53, 2355-2363, http://dx.doi.org/10.1194/jlr.M028878.

Xie, W., Li, M., Xu, N., Lv, Q., Huang, N., He, J., Zhang, Y., 2013. miR-181a regulates inflammation responses in monocytes and macrophages. PLoS One 8, e58639, http://dx.doi.org/10.1371/journal.pone.0058639.

Xu, C., Ren, G., Cao, G., Chen, Q., Shou, P., Zheng, C., Du, L., Han, X., Jiang, M., Yang, Q., Lin, L., Wang, G., Yu, P., Zhang, X., Cao, W., Brewer, G., Wang, Y. Shi, Y., 2013. MiR-155 regulates immune modulatory properties of mesenchymal stem cells by targeting TAK1-binding protein 2. Journal of Biological Chemistry.

Xu, D., Takeshita, F., Hino, Y., Fukunaga, S., Kudo, Y., Tamaki, A., Matsunaga, J., Takahashi, R.U., Takata, T., Shimamoto, A., Ochiya, T., Tahara, H., 2011. miR-22 represses cancer progression by inducing cellular senescence. Journal of Cell Biology 193, 409-424, http://dx.doi.org/10.1083/jcb.201010100

Yao, R., Ma, Y., Du, Y., Liao, M., Li, H., Liang, W., Yuan, J., Ma, Z., Yu, X., Xiao, H., Liao, Y., 2011. The altered expression of inflammation-related microRNAs with microRNA-155 expression correlates with Th17 differentiation in patients with acute coronary syndrome. Cellular and Molecular Immunology 8, 486-495, http://dx.doi.org/10.1038/cmi.2011. 22.

Yao, Q. Cao, Z., Tu, C.,Zhao, Y., Liu, H.,Zhang, S., 2013. MicroRNA-146a acts as a metastasis suppressor in gastric cancer by targeting WASF2. Cancer Letters (February), http://dx.doi.org/10.1016/j. canlet.2013.02.031 (pii: S0304-3835(13) $-00157-2)$.

Yang, J., Lan, H., Huang, X. Liu, B., Tong, Y., 2012. MicroRNA-126 inhibits tumor cell growth and its expression level correlates with poor survival in non-small cell lung cancer patients. PLoS One 7, e42978, http://dx.doi.org/10.1371/journal.pone.0042978.

Yang, Z., Ming, X.F., 2012. mTOR signalling: the molecular interface connecting metabolic stress, aging and cardiovascular diseases. Obesity Reviews 12, 58-68, http://dx.doi.org/10.1111/j.1467-789X.2012.01038.x (Review).

Yang, M., Shen, H., Qiu, C., Ni, Y., Wang, L., Dong, W., Liao, Y., Du, J., 2013. High expression of miR-21 and miR-155 predicts recurrence and unfavourable survival in non-small cell lung cancer. European Journal of Cancer 49, 604-615, http://dx.doi.org/10.1016/j. ejca.2012.09.031.

Yu, J.M., Wu, X., Gimble, J.M., Guan, X., Freitas, M.A., Bunnell, B.A., 2011. Age-related changes in mesenchymal stem cells derived from rhesus macaque bone marrow. Aging Cell 10, 66-79, http://dx.doi.org/10.1111/j.1474-9726.2010.00646.x.
Zampetaki, A., Willeit, P., Tilling, L., Drozdov, I., Prokopi, M., Renard, J.M., Mayr, A. Weger, S., Schett, G., Shah, A., Boulanger, C.M., Willeit, J., Chowienczyk, P.J., Kiechl, S., Mayr, M., 2012. Prospective study on circulating MicroRNAs and risk of myocardial infarction. Journal of the American College of Cardiology 60, 290-299, http://dx.doi.org/10.1016/j.jacc.2012.03.056.

Zhang, D.Y., Wang, H.J., Tan, Y.Z., 2011. Wnt/ $\beta$-catenin signaling induces the aging of mesenchymal stem cells through the DNA damage response and the p53/p21 pathway. PLoS One 6, e21397, http://dx.doi.org/10.1371/journal.pone.0021397.

Zhao, B., Benson, E.K., Qiao, R., Wang, X., Kim, S., Manfredi, J.J., Lee, S.W. Aaronson, S.A., 2009. Cellular senescence and organismal ageing in the absence of p21(CIP1/WAF1) in ku80(-/-) mice. EMBO Reports 10, 71-78, http://dx.doi.org/10.1038/embor.2008.220.

Zhao, T., Li, J., Chen, A.F., 2010. MicroRNA-34a induces endothelial progenitor cell senescence and impedes its angiogenesis via suppressing silent information regulator 1. American Journal of Physiology - Endocrinology and Metabolism 299, E110-E116, http://dx.doi.org/10.1152/ajpendo.00192.2010.

Zhao, J.L., Rao, D.S., Boldin, M.P., Taganov, K.D., O'Connell, R.M., Baltimore, D., 2011. NF-kappaB dysregulation in microRNA-146a-deficient mice drives the development of myeloid malignancies. Proceedings of the National Academy of Sciences of the United States of America 108, 9184-9189, http://dx.doi.org/10.1073/pnas.1105398108.

Zhong, X., Chung, A.C., Chen, H.Y., Dong, Y., Meng, X.M., Li, R., Yang, W., Hou, F.F., Lan, H.Y., 2013. miR-21 is a key therapeutic target for renal injury in a mouse model of type 2 diabetes. Diabetologia.

Zhou, J., Wang, K.C., Wu, W., Subramaniam, S., Shyy, J.Y., Chiu, J.J., Li, J.Y., Chien, S. 2011. MicroRNA-21 targets peroxisome proliferators-activated receptor-alpha in an autoregulatory loop to modulate flow-induced endothelial inflammation. Proceedings of the National Academy of Sciences of the United States of America $108,10355-10360$

Zhou, S., Greenberger, J.S., Epperly, M.W., Goff, J.P., Adler, C., Leboff, M.S., Glowacki, J., 2008. Age-related intrinsic changes in human bone-marrow-derived mesenchymal stem cells and their differentiation to osteoblasts. Aging Cell 7, 335-343, http://dx.doi.org/10.1111/j.1474-9726.2008.00377.x.

Zhu, S., Deng, S., Ma, Q., Zhang, T., Jia, C., Zhuo, D., Yang, F., Wei, J., Wang, L., Dykxhoorn, D.M., Hare, J.M., Goldschmidt-Clermont, P.J., Dong, C., 2013. MicroRNA-10A* and MicroRNA-21 modulate endothelial progenitor cell senescence via suppressing high-mobility group A2. Circulation Research 112, 152-164, http://dx.doi.org/10.1161/CIRCRESAHA.112.280016.

Zhu, X. Li, H. Long L, Hui, L. Chen, $\mathrm{H}$., Wang, X, Shen, H., Xu, W., 2012. miR-126 enhances the sensitivity of non-small cell lung cancer cells to anticancer agents by targeting vascular endothelial growth factor A. Acta Biochimica et Biophysica Sinica (Shanghai) 44, 519-526, http://dx.doi.org/10.1093/abbs/gms026.

Zoncu, R., Efeyan, A., Sabatini, D.M., 2011. mTOR: from growth signal integration to cancer, diabetes and ageing. Nature Reviews Molecular Cell Biology 12, 21-35, http://dx.doi.org/10.1038/nrm3025. 